Illinois State University

ISU ReD: Research and eData

Theses and Dissertations

3-31-2014

\title{
Effects of River Stages and Barge Rates on Illinois Corn and Soybean Basis
}

Zachary Gass

Illinois State University, zdgass@gmail.com

Follow this and additional works at: https://ir.library.illinoisstate.edu/etd

Part of the Agricultural and Resource Economics Commons, and the Agricultural Economics Commons

\section{Recommended Citation}

Gass, Zachary, "Effects of River Stages and Barge Rates on Illinois Corn and Soybean Basis" (2014).

Theses and Dissertations. 157.

https://ir.library.illinoisstate.edu/etd/157

This Thesis is brought to you for free and open access by ISU ReD: Research and eData. It has been accepted for inclusion in Theses and Dissertations by an authorized administrator of ISU ReD: Research and eData. For more information, please contact ISUReD@ilstu.edu. 
EFFECTS OF RIVER STAGES AND BARGE RATES

ON ILLINOIS CORN AND SOYBEAN BASIS

\author{
Zachary D. Gass
}

57 pages

May 2014

During the drought of 2012 the Midwest suffered one of the worst droughts to date which created adverse effects on multiple sectors of the agriculture economy including river transportation. During the last week of 2012, grain barge movement decreased by 41 percent from the same period in 2011. This thesis identifies the relationship between river stages, barge rates, and Illinois corn and soybean basis. By implementing simple regression techniques, river stages and barge were each used as an independent variable and experimental region basis minus control region basis was used as the dependent variable. Multiple regression techniques combined both river stages and barge rates as independent variables and experimental region basis minus control region basis was used as the dependent variable. Results showed that basis levels were impacted during drought and flood stages. Results also showed that drought and flood stages and barge freight rates also influenced basis levels relative to the control region. 
EFFECTS OF RIVER STAGES AND BARGE RATES

ON ILLINOIS CORN AND SOYBEAN BASIS

ZACHARY D. GASS

A Thesis Submitted in Partial Fulfillment of the Requirements for the Degree of

MASTER OF SCIENCE

Department of Agriculture

ILLINOIS STATE UNIVERSITY

2014 
(C) 2014 Zachary D. Gass 
EFFECTS OF RIVER STAGES AND BARGE RATES

ON ILLINOIS CORN AND SOYBEAN BASIS

ZACHARY D. GASS

COMMITTEE MEMBERS:

Rick C. Whitacre

Kerry Tudor

Aslihan D. Spaulding 


\section{ACKNOWLEDGEMENTS}

This thesis is dedicated to my friends and family who have offered support throughout my years of study. Primarily, this thesis is dedicated to my mother, Mary Ellen, for teaching me that with courage and dedication, anything is possible. I would also like to extend my thanks to the Department of Agriculture at Illinois State University along with my thesis committee for their continuous support during this project.

Z.D.G. 


\section{CONTENTS}

\section{Page}

ACKNOWLEDGEMENTS

CONTENTS

TABLES

FIGURES

vi

CHAPTER

I. BACKGROUND

Drought of 2012

1

Understanding Basis

2

How Basis Is Used

3

Understanding Barge Rates

Understanding River Stages

II. REVIEW OF RELATED LITERATURE

Literature Review

$\begin{array}{ll}\text { III. RESEARCH DESIGN } & 13\end{array}$

$\begin{array}{ll}\text { Objective } & 13\end{array}$

Approach 13

Data Construction 15

$\begin{array}{ll}\text { Methodology } & 17\end{array}$

$\begin{array}{ll}\text { Data Considerations } & 18\end{array}$

$\begin{array}{ll}\text { IV. } & 19\end{array}$

Results 19

River Stages $\quad 19$

Barge Rates $\quad 26$

Multiple Regressions $\quad 31$

V. CONCLUSIONS 39 
1. 1988 River Stage: Corn 21

2. 1988 River Stage: Soy 21

3. 1993 River Stage: Corn $\quad 22$

4. 1993 River Stage: Soy 22

5. 2008 River Stage: Corn 23

6. 2008 River Stage: Soy 23

7. 2011 River Stage: Corn 24

8. 2011 River Stage: Soy 24

9. 2012 River Stage: Corn 25

10. 2012 River Stage: Soy 25

11. 1988 Barge Rate: Corn 27

12. 1988 Barge Rate: Soy 27

13. 1993 Barge Rate: Corn $\quad 27$

14. 1993 Barge Rate: Soy 28

15. 2008 Barge Rate: Corn 28

16. 2008 Barge Rate: Soy 29

17. 2011 Barge Rate: Corn 29

18. 2011 Barge Rate: Soy 30

19. 2012 Barge Rate: Corn 30

20. 2012 Barge Rate: Soy 31 
21. 1988 Multiple: Corn

22. 1988 Multiple: Soy

23. 1993 Multiple: Corn

24. 1993 Multiple: Soy

25. 2008 Multiple: Corn

26. 2008 Multiple: Soy

27. 2011 Multiple: Corn 35

28. 2011 Multiple: Soy 36

29. 2012 Multiple: Corn 37

30. 2012 Multiple: Soy 


\section{FIGURES}

Figure

Page

1. Basis Terminology and Movement

2. Representation of a Basic Corn Hedge Using March Corn Futures

3. Benchmarks and Respective Barge Rates

4. Map of Illinois Agricultural Regions and Waterways

5. Map of Illinois Agricultural Regions, Waterways, and River Gage Locations 
CHAPTER I

\section{BACKGROUND}

\section{Drought of 2012}

According to the United States Department of Agriculture (USDA), during the week ending December 22nd, 2012, barge grain movements totaled 440,432 tons, 18.5 percent lower than the previous week and 41 percent lower than the same period in 2011. (Grain Transportation Report, 2012) This reduction in grain movement on our nation's rivers was due to the severe drought of 2012 in which low water stages on the Mississippi, Illinois, and Ohio Rivers forced barges to run aground and grain industries to significantly decrease barge-loading capacity. The combination of low river stages and reduced barge traffic subsequently affected the grain marketing channel throughout the state of Illinois.

In response to navigability concerns on the Mississippi River, industry officials, along with fifteen senators and sixty-two congressmen, drafted a letter to President Barack Obama requesting an emergency directive to facilitate river improvements. This directive also urged the United States Army Corp of Engineers (USACE) to begin dredging and rock removal along critical stretches of the river. The focus of the directive and respective operations was to improve river navigability thus improving barge movement and stabilizing the already volatile grain industry that depends on barge commerce. 
Among all transportation modes the grain industry utilizes, barge transportation is the most economical, allowing grain to be moved from production areas to export facilities. According to Brown (2002), the Mississippi and Illinois rivers transport 50 percent of total U.S corn and 40 percent of total U.S. soybeans moving to the export market (Brown, 2002). According to the National Agricultural Statistics Service (NASS), the state of Illinois is typically the top soybean producing and the second most corn producing state in the United States. Since both the Mississippi and Illinois rivers navigate through or border Illinois, it is easy to see how poor river conditions can affect grain economics within the state. When rivers become less navigable and barge transportation decreases during times of volatile river stages, other markets such as freight are also affected.

\section{Understanding Basis}

Basis can best be defined as the difference between the local cash grain price and the price of the nearby futures month. Understanding the fundamentals of basis is important for both commodity market participants and producers since this is the value most grain businesses use to trade grain. Basis is used to determine multiple things such as the best time to buy or sell, when to use the futures market to hedge, and when to accept an offer or bid from a supplier or buyer. Past research has not only shown that the ability to predict basis is important when placing hedges but understanding the multiple factors that influence basis are important as well. Researcher such as Garcia and Good (1983), Kahl and Curtis (1986), Martin, Groenwegen, and Pidgeon (1980), and Tilley and Campbell (1988) have all conducted studies that identify factors affecting basis. These are factors include storage capacity, grain stocks, competition, and transportation costs. 
As the grain marketing year progresses, basis values often fluctuate depending on local market conditions. These market conditions include transportation costs, local supply and demand, and availability of supplies. In grain surplus areas of the United States basis is usually weaker while basis values in grain deficit of the country areas are usually stronger. (Lorton and White, 2010). Much like futures prices, basis levels vary over periods of time and strengthen or weaken depending on supply and demand conditions in the marketplace. When local cash price is increasing compared to the relative futures month, basis is said to be strengthening. When local cash price is decreasing compared to the relative futures month, basis is said to be weakening. Figure 1 below illustrates the strengthening and weakening of basis

Figure 1. Basis Terminology and Movement

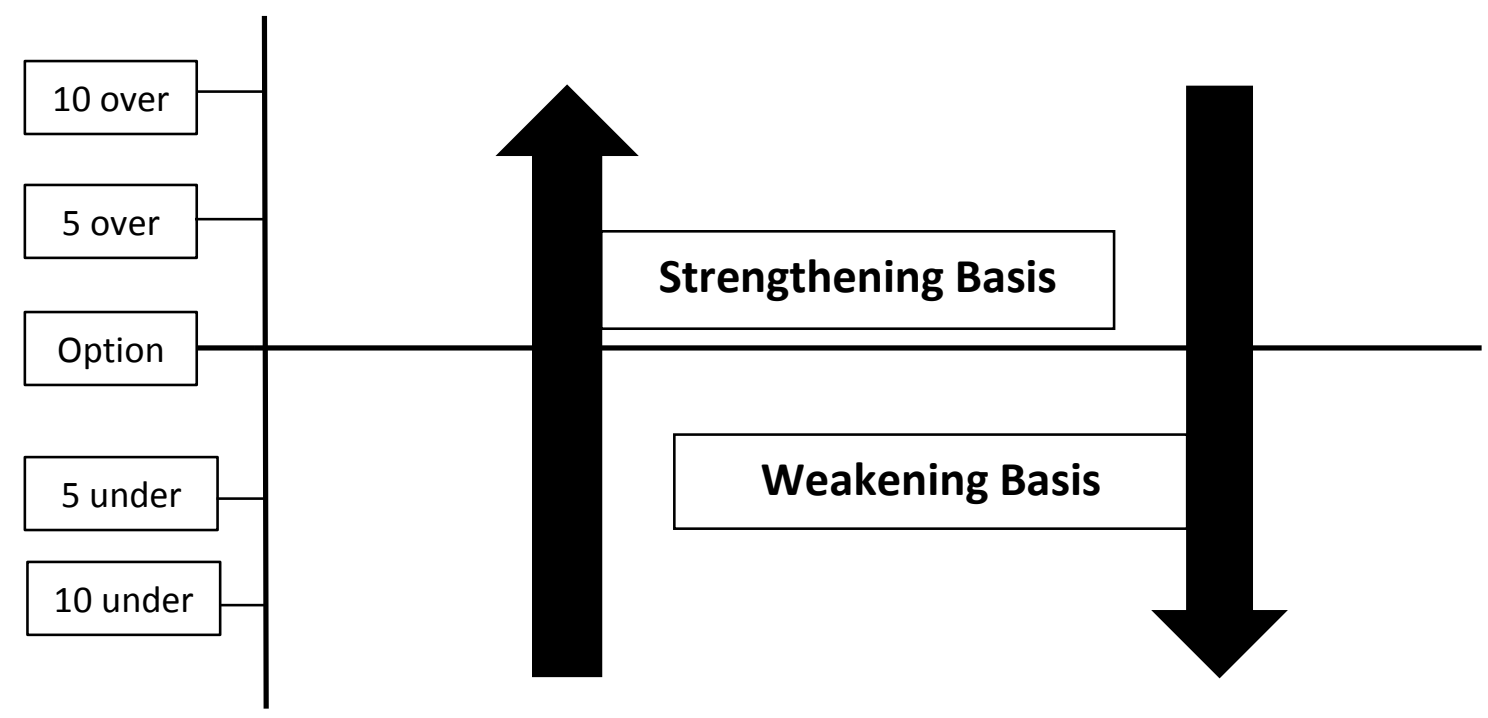

\section{How Basis Is Used}

It is important to understand the seasonality of basis and the patterns basis levels follow as the crop year progresses. Although prices can change from year to year, basis levels tend to be fairly predictable based on historical patterns. Market participants can easily keep track of basis by recording the date, cash price, futures price, and factors believed to be affecting basis. 
For example, recording historical basis data allows a producer to construct a marketing plan to allow for optimal returns on his or her crops. Furthermore, many grain elevators and processors offer basis contracts to producers. A basis contract is an agreement establishing that the price paid for grain to the seller will be the price of a specified futures contract on the day of the seller's choosing, minus the basis that existed at the time the contract was written. A basis contract fixes the basis and allows the seller to speculate on the futures price (Whitacre \& Spaulding, 2007). In other words, a basis contract locks in the basis and delivery period without specifying the futures price. This then allows the producer to speculate on futures price.

Merchandisers for grain companies also utilize basis in grain marketing decisions. By trading basis, money is made as a result of the execution of a cash and futures transaction. Executing a transaction in the futures opposite the cash eliminates price risk and establishes a basis level. The merchandiser then waits for a favorable move in the basis to complete the trade by offsetting cash and futures transactions (Lorton and White, 2010). Figure 2 below illustrates a basis hedge after a cash corn purchase.

Figure 2. Representation of a Basic Corn Hedge Using March Corn Futures

\begin{tabular}{|c|c|c|c|c|c|}
\hline & \multicolumn{2}{|l|}{ Cash } & \multicolumn{2}{|l|}{$\begin{array}{c}\text { March } \\
\text { Futures }\end{array}$} & Basis \\
\hline & Buy & Sell & Buy & Sell & \\
\hline Step 1 & $\$ 2.30$ & & & $\$ 2.60$ & +30 \\
\hline Step 2 & & $\$ 2.00$ & $\$ 2.10$ & & -10 \\
\hline & 30 cent loss & & 50 cent gain & & $\begin{array}{l}20 \text { cent net } \\
\text { profit }\end{array}$ \\
\hline
\end{tabular}

Example taken from pg. 8 of The Art of Grain Merchandising (Lorton \& White, 2010) 


\section{Understanding Barge Rates}

As previously stated, when unstable river conditions develop during drought and flood occurrences, other markets are influenced. Barge freight is traded similar to how commodity markets are traded. The freight market is subject to external factors that affect the supply and demand for freight on rivers. These factors include market liquidity, export demand, Northbound shipments, river conditions, lock delays, accidents, weather, water levels, accidents, Gulf delays, market spreads for commodities, and power on the river, or availability of tugs to push barges. Freight merchandisers are constantly monitoring these factors, allowing them to make decisions on whether to be long or short barge freight.

According to the Agricultural Marketing Service (AMS) provided by the USDA, the U.S. Inland Waterway System utilizes a percent of tariff system to establish barge freight rates. These tariffs were first established by the Bulk Grain and Grain Products Freight Tariff No. 7, issued by the Waterways Freight Bureau (WFB) of the Interstate Commerce Commission (ICC). Although Tariff No. 7 is no longer used today, the benchmarks and tariffs that were established in 1976 are.

Barge freight is quoted on a dollar per ton basis and often carries a minimum tonnage requirement of 1,450 and 1,600 tons, or about 50,000 bushels of grain. This calculation multiplies the percent of tariff by the 1976 benchmark. Port locations on the Mississippi, Illinois, and Ohio Rivers are categorized under benchmarks. Table 3 provides example of port locations, their respective benchmark, and a freight rate. Notice the more Southern port locations and benchmarks on the Mississippi River have cheaper barge rates compared to the Northern-most locations. This is explained by the number of locks, and therefore subsequent delays, on the Upper Mississippi compared to the scarce amount of locks on the Lower Mississippi. 
Figure 3: Benchmarks and Respective Barge Rates

\begin{tabular}{|c|c|c|}
\hline Benchmark & Rate & Ports Included \\
\hline TWC: Twin Cities & 619 & Minneapolis, St. Paul \\
\hline MM: Mid-Miss & 532 & Alton, STL, Cape Girardeau \\
\hline St. Louis & 399 & Beardstown, Havana \\
\hline Illinois & 464 & Cincinnati \\
\hline CINC & 469 & Louisville \\
\hline Lower Ohio & 446 & New Madrid, Cairo \\
\hline Cairo-Mem & 314 & \\
\hline
\end{tabular}

Table provided by the Agricultural Marketing Service of the USDA

\section{Understanding River Stages}

This thesis utilizes river stages during periods of drought and flood. River stages are commonly referred to as water levels, or river levels, and are monitored by the United States Army Corp of Engineers (USACE) and the United States Geological Survey (USGS). Both organizations work in conjunction to monitor river conditions as well as provide real-time data for the use by industry participants. River gages are placed along the banks of the Mississippi, Illinois, and Ohio Rivers, providing measurements of water surface elevation, or river stage, data. River stages are based on gage zero which is derived from sea level elevation. Each river gage location has drought and flood parameters, outlining thresholds the river must cross to be deemed a drought or flood stage. 
The objective of this thesis was to identify the relationship between river stages, barge rates, and the impact these two variables have on Illinois corn and soybean basis. This thesis provides further knowledge in understanding the fundamentals of basis along with the identification of additional factors that influence grain basis movements. 
CHAPTER II

\section{REVIEW OF RELATED LITERATURE}

\section{Literature Review}

Hieronymus (1977) in his book entitled Economics of Futures Trading states that basis and spreads are a function of the market price of storage, or the cost of storing the cash commodity. "Commodities move into storage when the price of storage is favorable and move out of storage when the price is unfavorable." (Hieronymus, 1977) Hieronymus also offers that basis and spreads are relative to the supply and demand of available storage space. During times of increased grain flow, the cash price is weak in relation to the nearby futures and the spreads are wide. However, when grain is not flowing at a fast pace and demand is high, the price of storage decreases.

Martin, Groenwegen, and Pidgeon (1980) examined factors that affect corn basis in Southwestern Ontario. According to the authors, most basis fluctuations are explained by variables with local market conditions. During the fall months the size of the Canadian and U.S. crop is the most important factor influencing corn basis. During winter months, when waterbased navigation is closed, the most significant factor is the size of the Canadian crop relative to local demand. Once water-based grain movement occurs in the spring, both local production and the availability of western feed grains have significant effects on corn basis (Martin et al, 1980). 
Garcia and Good (1983) identified and quantified factors that determine the magnitude of corn basis in Illinois from 1971 to 1981 . The authors provided an overview of the theory of basis and then developed a model to further explain basis variations throughout the state of Illinois. Historically, one must not only consider the cost of storage and transportation, but the supply and demand for storage. The magnitude of the basis is influenced by three sets of factors: cost, stock, and flow factors. (Garcia and Good, 1983) After observing basis relationships for corn, the authors concluded that during harvest periods local production relative to available storage impacts basis along with the structure of storage costs. During post-harvest periods, transportation costs have a greater impact on basis however during the immediate harvest, stock and production factors have a great impact than transportation cost factors. Lastly, Garcia and Good concluded that larger inventories relative to available storage space are highly associated with transportation demand. The statewide basis pattern is consistent with reported grain flow and differences in barge rates along certain waterway segments. (Garcia and Good, 1983)

Kahl and Curtis (1986) analyzed corn basis in South Carolina and Illinois, grain deficit and grain surplus areas, respectively. The author's objective was to identify factors that influence the magnitude and variation of basis levels in these two regions. The variables included in the model were corn basis, log of corn stocks, log of soybean stocks, storage, average cash price, livestock and poultry log, and transportation costs. Kahl and Curtis concluded the corn basis in South Carolina was found to be significant and negatively related to the inventories of corn stocks and state storage costs. A positive relationship was found between the basis and soybean stocks, livestock and poultry logs, and U.S. transportation costs. Corn basis in Illinois was determined insignificant and negatively related to soybean stocks and state storage costs but significant and 
positively related to cash price. Illinois corn basis was found to be significant and positively related to U.S. transportation costs. (Kahl and Curtis, 1986)

Naik and Leuthold (1991) examined components of the corn basis utilizing a general theory of intertemporal price relationships for storable commodities. The authors used their own previous research to aid in their conclusions, and also used Keynes' theory of normal backwardation, or risk premium, and Working's theory of price of storage. These two contradicting theories are used to examine basis relationships. Keynes' theory of normal backwardation states that hedgers participate in the futures market to shift the risk of price change to speculators by paying a premium. (Keynes, 1923, 1930) Working's theory of price of storage disagrees with Keynes' theorizing that hedgers participate in futures markets to capture profits arising out of changes in the movements of cash and futures prices. (Working, 1949) This means the arbitrage opportunities exist when favorable basis is greater than the net carrying cost. Naik and Leuthold's research concluded that basis consists of a risk premium, a speculative component, and a maturity basis risk from other factors such as storage costs for storable commodities. The existence of the futures market reduces price risk, but does not eliminate it. (Naik and Leuthold, 1991)

Tilley and Campbell (1988) evaluated the performance of the Gulf-Kansas City hard-red winter wheat basis and evaluated the impact government programs at the farm level can have on basis. The author's most significant conclusion is that the Gulf-Kansas City HRW wheat basis is accurately reflecting fundamental changes in the market. Tilley and Campbell conclude that government programs that restrict wheat availability significantly impact basis. When these government programs occur, they are most significantly impacting basis during times of high export demand. Conversely, when government programs allow more wheat to flow to market, 
free stocks increase and reduce the impact of export demand on the basis. (Tilley and Campbell, 1988)

McKenzie (2005) investigated the response of Arkansas Delta and Gulf soybean basis levels to barge shocks from April 1966 to December 1999. By collecting basis and barge rate information for this time period McKenzie was able to quantify the response of Memphis and Little Rock markets to significant changes in barge rates. McKenzie's study found convincing evidence that the grain marketing system, and price discovery, is effective. McKenzie (2005) concludes that the Gulf terminal market is an important price discovery market which transmits pricing signals to other marketing regions such as the Memphis, Little Rock, and other Arkansas markets. Increases in barge rates, or barge shocks, translate into higher transportation costs. This pricing signal is transmitted across the marketing system and eventually leads to lower basis offers at the farm level. (McKenzie, 2005)

Mass and Waller (2001) observed wheat basis level movements during a 16-year period to identify which factors producers could use to more effectively forecast future basis movements. The two reporting areas in their study where North of the Canadian River in the Texas Panhandle and the Houston port. The independent variables of this study included monthly observations of a three-year average of basis, a stocks/use ratio, export inspections, and binary variables to adjust for special events such as the 1996 Farm Bill. Maas and Waller concluded that producers should consider marketing their wheat during early harvest when basis levels are more favorable compared to the September/October time frame basis. If producers can lock in basis premiums during harvest, they should do so because storage returns are unlikely as the crop year progresses. Changes in the ending stock/ratio, and export inspections can help producers understand what is happening to basis currently, and should 
help them formulate expectations about what my happen to basis in the future. (Maas and Waller, 2001) 
CHAPTER III

\section{RESEARCH DESIGN}

\section{Objective}

The objective of this thesis was to identify the relationship between river stages, barge rates, and the impact these two variables have on Illinois corn and soybean basis. Past research outlined multiple factors known to influence basis level movements. However, past research has not identified whether or not environmental factors, such as river stages during drought or flood stages, have any impact on basis. Transportation factors, such as barge rates, have been shown to influence basis.

\section{Approach}

To better understand the influence barge rates and river stages have on Illinois corn and soybean basis, the seven agricultural regions of Illinois were used. The agricultural regions of Illinois are as follows: Northern, Western, North Central, South Central, Wabash, West Southwest, and Little Egypt. These regions were chosen because basis data that was extracted from the University of Illinois FarmDoc website categorizes basis levels in Illinois by these seven regions. Figure 4 shows the seven agricultural regions of Illinois. Each region examined in this study is important because one of the three rivers studied either borders or navigates through each respective region. The three rivers are the Mississippi, Illinois, and Ohio Rivers all of 
which are monitored by the United States Geological Survey (USGS) and the United States Army Corp of Engineers (USACE).

Figure 4.Map of Illinois Agriculture Regions and Waterways
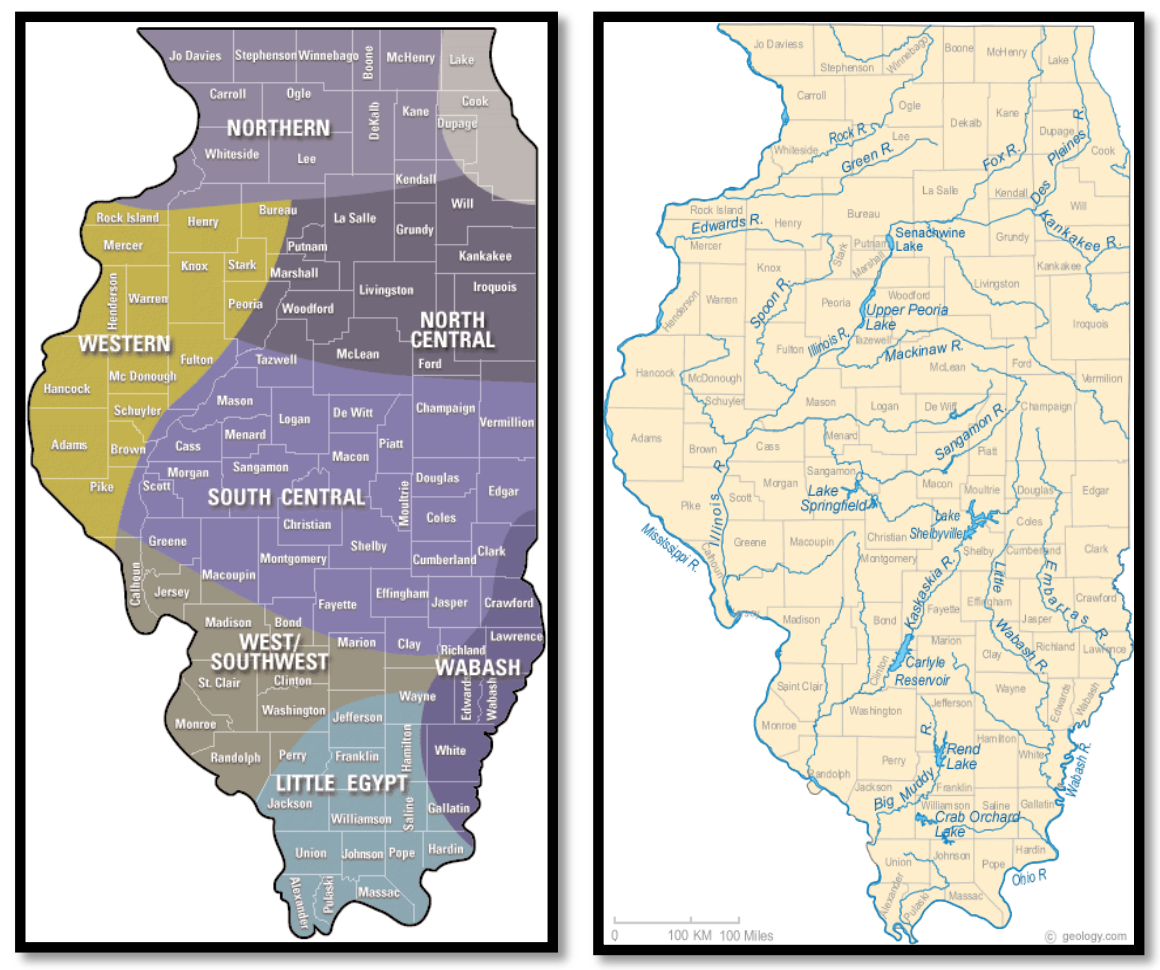

Pictures provided by the University of Illinois FarmDoc website

Research design deems the North Central region as the control region with the Northern, Western, South Central, Wabash, West Southwest, and Little Egypt regions as experimental regions. Although the Illinois River does navigate through it, the North Central region is more land-locked, or insulated, within the state. Likewise, the northern reaches of the Illinois River are more controlled by the lock and dam system allowing for river stages to be steadier or less volatile during drought and flood occurrences. Furthermore, each experimental region's basis movements will be compared to the North Central region's control basis. 
Since this study utilizes river stages and barge rates as possible factors affecting grain basis changes in Illinois, it is important to examine years where drought and flood conditions affected the Midwestern waterways. The years used in this study are 1988, 1993, 2008, 2011, and 2012. During the years of 1988 and 2012 the nation experienced two detrimental droughts. The Great Flood of 1993 is arguably the most costly flood to ever occur in the United States and during the years of 2008 and 2011, drought and flood occurrences were common throughout the Midwest.

\section{Data Construction}

As previously mentioned, basis data for this study was obtained using the University of Illinois' FarmDoc website. The Marketing and Outlook section of this site provides an Illinois Regional Basis Decision Tool where historical corn and soybean basis for the seven regions of Illinois are presented. The Illinois Regional Basis Decision Tool shows weekly basis averages for each region and basis levels are displayed against the December, March, and July futures. This study utilized basis versus July futures based on the availability of basis data and because it is one of the last futures month for both corn and soybeans before the new crop time frame. Although each commodity is traded against later futures months closer to harvest, July $(\mathrm{N})$ is a uniform futures month for both commodities.

River stage data was collected using the United States Geological Survey (USGS) and the United States Army Corp of Engineers (USACE) websites. Both organizations utilize river gages to constantly monitor river conditions. River gages are devices used to monitor real-time river stages levels. Each gage measurement is based on gage datum, or gage zero, which is derived from sea level elevation. Selected river gages for this study are as follows: Mississippi River near Fulton, IL (Northern region), Mississippi River at Quincy, IL (Western region), Illinois River at 
Marseilles, IL (North Central control region), Illinois River at Copperas Creek, IL (South Central region), Ohio River near Old Shawneetown, IL (Wabash region), Mississippi River at Chester, IL (West Southwest region), and Mississippi River at Thebes, IL (Little Egypt region). Gages were selected based on geographic location respective to each experimental region and availability of river data for historical years. Figure 5 shows the location of each river gage.

Figure 5: Map of Illinois Agricultural Regions, Waterways, and River Gage Locations
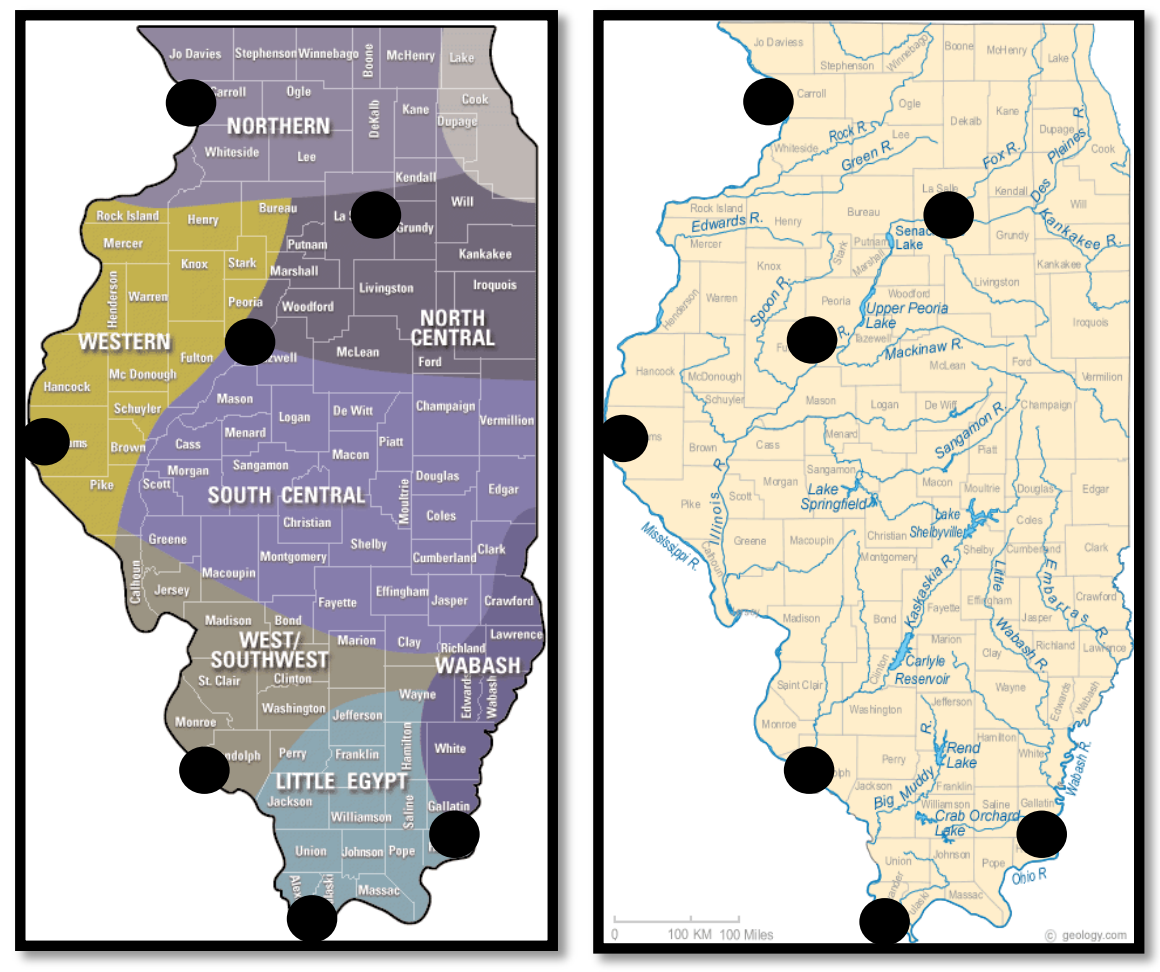

Pictures provided by the University of Illinois FarmDoc website

Barge rate data was collected using grain transportation publications provided by the Agricultural Marketing Service (AMS) which is sponsored by the United States Department of Agriculture (USDA). These grain transportation reports provide barge freight quotes for the 
Mississippi, Illinois, and Ohio Rivers. Barge rates are categorized and benchmarked based on location on the river. This study will utilize Middle Mississippi (MM), Illinois River (ILL), Saint Louis (STL), and Lower Ohio (LOH) rates.

\section{Methodology}

The dependent variable in this study is basis in the experimental region minus basis in the control region. This allows one observation of basis level differences and movements between each region during weeks of drought or flood. By implementing this method, results show which region varies the most from the control region during action occurrences. River stages and barge rates are the independent variables in this study. Each river gage in this study has drought and flood parameters. When these parameters are crossed, either a drought and flood stage has occurred. This study collected the respective basis, river stage, and barge rate data during these periods.

The statistical methodology consists of 304 regression tests, 206 being simple linear regression techniques and 98 being multiple regression techniques. Each drought and flood occurrence during 1988, 1993, 2008, 2011, and 2012 are examined. Depending on year and region location, some regions of Illinois do not enter drought or flood stage and therefore are not represented in regression results. Simple linear regressions interchange the two independent variables, river stages and barge rates. Multiple regressions use both independent variables to establish if both variables together have a larger impact on basis.

\footnotetext{
(Region Basis - Control Basis $)=f($ River Stages $)$$$
\text { (Region Basis }- \text { Control Basis })=f(\text { Barge Rates })
$$$$
\text { (Region Basis }- \text { Control Basis) }=\mathrm{f} \text { (River Stages, Barge Rates) }
$$ 


\section{Data Considerations}

There a few considerations to highlight regarding data collection. During 1988 and 1993, river stage data for the Wabash region was unavailable simply because the gage was not implemented until a later date. Although the absence of data does affect research results, it is important to understand that this gage provided the most data when compared to other gages located on the Ohio River for the Wabash region.

Barge rate data during end of the year holidays was also absent during data collection. Personnel employed by the USDA were not present during the holiday season to collect barge rate information. Therefore, barge rate information towards the end of December is absent. This was not expected to influence regression results as the Mississippi River is commonly frozen during this time and barge traffic is relatively nonexistent. 


\section{CHAPTER IV}

\section{ANALYSIS OF DATA}

\section{Results}

After conducting 206 simple linear regressions and 98 multivariate regressions it is apparent there is a significant relationship between river stages, barge rates, and Illinois corn and soybean basis level movements. Several simple regression models displayed significant correlation between either river stages or barge rates basis level movements in Illinois but the greatest significance came from the multivariate regressions. The results are divided into tables by year, commodity, and dependent variable. Action stage denotes whether the observations occurred during a drought or flood stage of the regions' respective river. Number of observations are shown as (n) and each observation represents a week. In the multiple regressions the beta coefficients are denoted by $(\beta)$ and $(\beta 2)$ and followed by each respective $p$ value ( $\mathrm{P}$ and $\mathrm{P} 2$ ) and t-statistic (tS and tS2). These results are found in Table 26 through Table 35. Although significant correlation between river stages, barge rates, and basis level movement in Illinois exists in the results, it is evident that basis movements are influenced by a complex set of factors.

\section{River Stages}

Among the simple linear regressions there were 18 out of 106 that showed correlation between river stages and basis level movements. The significant regressions occurred during 
drought and flood years and were observed in the Northern, Western, Wabash, West/Southwest, and Little Egypt regions of Illinois. These regressions illustrate the correlation between river stages and basis level movements but also indicate which regions' basis levels vary the most from the control region basis, or normal basis.

Results and respective scatter plots show that basis levels both strengthen and weaken as river stages increased and decreased during drought and flood occurrences. There are seven regressions, four corn and three soybean, and respective scatter plots that show as river stages rose during drought occurrences, or become more favorable for barge traffic, basis levels tended to strengthen relative to the control region as the weeks pass with improved water conditions. These occurrences showed that as river stages or conditions improve draft limitations for barges also improved, allowing river facilities to load barges with more grain. If river terminal operations are allowed to load barges heavier they then better serve export market demand thus strengthening basis levels. The river terminals in the experimental region likely issued a premium in basis to buy bushels into the river facility.

Conversely, there were eleven regression models that showed during both drought and flood periods, corn and soybean basis tended to weaken relative to the control region as river conditions either improved or worsend. There are seven regressions during drought occurrences where basis levels weakened as river conditions improved or river stages moved higher. During flood occurrences there are four regressions that illustrated basis levels weakening as river stages continued to worsen, or trended higher during flood conditions. These regression models suggest that outside, prevailing factors also affected basis level movements in the experimental regions. 
Table 1

1988 River Stage: Corn

\begin{tabular}{|c|c|c|c|c|c|c|c|}
\hline Observation Region & Action Stage & $\mathrm{n}$ & $\mathrm{R}^{2}$ & Intercept & Beta & P-value & t Stat \\
\hline Northern Region & Drought & 8 & 0.08 & -0.18 & 0.03 & 0.49 & 0.73 \\
\hline Northern Region $^{2}$ & Drought & 15 & 0.07 & -0.15 & 0.02 & 0.35 & 0.97 \\
\hline *Western Region & Drought & 7 & 0.67 & -0.14 & 0.03 & 0.02 & 3.17 \\
\hline Western Region $^{2}$ & Drought & 15 & 0.09 & -0.09 & 0.02 & 0.26 & 1.17 \\
\hline South Central Region & Drought & 6 & 0.16 & 0.21 & -0.06 & 0.43 & -0.87 \\
\hline West Southwest Region & Drought & 11 & 0.10 & 0.00 & 0.00 & 0.33 & -1.02 \\
\hline West Southwest Region ${ }^{2}$ & Drought & 15 & 0.04 & -0.02 & 0.00 & 0.49 & -0.72 \\
\hline *Little Egypt Region & Drought & 12 & 0.66 & 0.21 & -0.01 & 0.00 & -4.41 \\
\hline Little Egypt Region $^{2}$ & Drought & 15 & 0.00 & 0.09 & 0.00 & 0.94 & 0.07 \\
\hline
\end{tabular}

Table 2

1988 River Stage: Soy

\begin{tabular}{|c|c|c|c|c|c|c|c|}
\hline Observation Region & Action Stage & $\mathrm{n}$ & $R^{2}$ & Intercept & Beta & P-value & t Stat \\
\hline Northern Region & Drought & 8 & 0.00 & -0.10 & 0.00 & 0.99 & 0.01 \\
\hline *Northern Region ${ }^{2}$ & Drought & 15 & 0.38 & -0.53 & 0.09 & 0.01 & 2.82 \\
\hline *Western Region & Drought & 7 & 0.57 & -0.23 & 0.05 & 0.05 & 2.56 \\
\hline Western Region $^{2}$ & Drought & 15 & 0.17 & -0.23 & 0.05 & 0.12 & 1.66 \\
\hline South Central Region & Drought & 6 & 0.02 & -0.03 & 0.04 & 0.77 & 0.31 \\
\hline West Southwest Region & Drought & 11 & 0.03 & 0.00 & 0.00 & 0.60 & 0.54 \\
\hline West Southwest Region ${ }^{2}$ & Drought & 15 & 0.11 & -0.03 & 0.01 & 0.22 & 1.28 \\
\hline *Little Egypt Region & Drought & 12 & 0.30 & 0.21 & -0.01 & 0.06 & -2.09 \\
\hline Little Egypt Region $^{2}$ & Drought & 14 & 0.01 & 0.01 & 0.00 & 0.67 & 0.44 \\
\hline
\end{tabular}


Table 3

1993 River Stage: Corn

\begin{tabular}{|c|c|c|c|c|c|c|c|}
\hline Observation Region & Action Stage & $\mathrm{n}$ & $\mathrm{R}^{2}$ & Intercept & Beta & P-value & $\mathrm{t}$ Stat \\
\hline Western Region & Flood & 6 & 0.21 & -0.05 & 0.00 & 0.36 & 1.04 \\
\hline Western Region $^{2}$ & Flood & 6 & 0.25 & -0.01 & 0.00 & 0.31 & -1.16 \\
\hline West Southwest Region $^{\text {West Southwest Region }}{ }^{2}$ & Flood & 8 & 0.02 & 0.02 & 0.00 & 0.77 & -0.31 \\
\hline Little Egypt Region $_{\text {Little Egypt Region }}$ & Flood & 6 & 0.48 & 0.05 & 0.00 & 0.13 & -1.91 \\
\hline & Flood & 3 & 0.68 & -0.06 & 0.00 & 0.38 & 1.45 \\
\hline
\end{tabular}

Table 4

1993 River Stage: Soy

\begin{tabular}{|c|c|c|c|c|c|c|c|}
\hline Observation Region & Action Stage & $\mathrm{n}$ & $\mathrm{R}^{2}$ & Intercept & Beta & P-value & $\mathrm{t}$ Stat \\
\hline Western Region & Flood & 6 & 0.17 & 0.02 & 0.00 & 0.41 & -0.91 \\
\hline Western Region $^{2}$ & Flood & 6 & 0.64 & 0.07 & -0.01 & 0.06 & -2.66 \\
\hline West Southwest Region $^{2}$ & Flood & 8 & 0.30 & 0.13 & 0.00 & 0.16 & -1.59 \\
\hline West Southwest Region $^{2}$ & Flood & 6 & 0.16 & 0.04 & 0.00 & 0.43 & -0.88 \\
\hline Little Egypt Region & Flood & 7 & 0.52 & -0.17 & 0.00 & 0.07 & 2.32 \\
\hline Little Egypt Region & Flood & 3 & 0.79 & 0.04 & 0.00 & 0.30 & -1.97 \\
\hline
\end{tabular}


Table 5

2008 River Stage: Corn

\begin{tabular}{|c|c|c|c|c|c|c|c|}
\hline Observation Region & Action Stage & $\mathrm{n}$ & $\mathrm{R}^{2}$ & Intercept & Beta & P-value & t Stat \\
\hline Northern Region & Drought & 9 & 0.02 & -0.20 & 0.03 & 0.69 & 0.42 \\
\hline Northern Region $^{2}$ & Drought & 3 & 0.04 & -0.20 & 0.03 & 0.88 & 0.20 \\
\hline Western Region & Flood & 5 & 0.09 & -0.27 & 0.01 & 0.62 & 0.54 \\
\hline Western Region $^{2}$ & Flood & 5 & 0.25 & -0.10 & 0.00 & 0.39 & -1.00 \\
\hline Wabash Region & Flood & 7 & 0.36 & 0.18 & 0.00 & 0.15 & -1.67 \\
\hline Wabash Region $^{2}$ & Drought & 3 & 0.10 & -0.11 & 0.01 & 0.80 & 0.33 \\
\hline *Wabash Region ${ }^{3}$ & Drought & 13 & 0.31 & -0.94 & 0.05 & 0.05 & 2.22 \\
\hline West Southwest Region & Flood & 17 & 0.16 & 0.17 & -0.01 & 0.11 & -1.70 \\
\hline West Southwest Region & Drought & 5 & 0.66 & 0.08 & -0.02 & 0.09 & -2.44 \\
\hline Little Egypt Region & Flood & 10 & 0.00 & 0.08 & 0.00 & 0.96 & -0.05 \\
\hline *Little Egypt Region ${ }^{2}$ & Flood & 5 & 0.92 & 0.60 & -0.01 & 0.01 & -6.01 \\
\hline *Little Egypt Region ${ }^{3}$ & Drought & 5 & 0.82 & 0.21 & -0.01 & 0.03 & -3.68 \\
\hline
\end{tabular}

Table 6

2008 River Stage: Soy

\begin{tabular}{|c|c|c|c|c|c|c|c|}
\hline Observation Region & Action Stage & $\mathrm{n}$ & $\mathrm{R}^{2}$ & Intercept & Beta & P-value & t Stat \\
\hline Northern Region & Drought & 9 & 0.00 & -0.04 & -0.03 & 0.87 & -0.17 \\
\hline Northern Region ${ }^{2}$ & Drought & 3 & 0.03 & -0.23 & 0.03 & 0.89 & 0.17 \\
\hline Western Region & Flood & 5 & 0.34 & 0.67 & -0.04 & 0.30 & -1.24 \\
\hline Western Region $^{2}$ & Flood & 5 & 0.35 & -0.44 & 0.01 & 0.29 & 1.27 \\
\hline Wabash Region & Flood & 7 & 0.00 & 0.03 & 0.00 & 0.93 & 0.09 \\
\hline Wabash Region $^{2}$ & Drought & 3 & 0.00 & -0.01 & 0.00 & 1.00 & 0.00 \\
\hline Wabash Region $^{3}$ & Drought & 13 & 0.00 & 0.00 & -0.01 & 0.86 & -0.18 \\
\hline West Southwest Region & Flood & 17 & 0.11 & 0.30 & -0.01 & 0.20 & -1.34 \\
\hline West Southwest Region & Drought & 5 & 0.39 & 0.29 & -0.04 & 0.26 & -1.39 \\
\hline Little Egypt Region & Flood & 10 & 0.29 & -0.57 & 0.02 & 0.11 & 1.79 \\
\hline Little Egypt Region ${ }^{2}$ & Flood & 5 & 0.05 & 0.16 & 0.00 & 0.72 & -0.40 \\
\hline Little Egypt Region ${ }^{3}$ & Drought & 5 & 0.54 & 0.48 & -0.05 & 0.16 & -1.86 \\
\hline
\end{tabular}


Table 7

2011 River Stage: Corn

\begin{tabular}{|c|c|c|c|c|c|c|c|}
\hline Observation Region & Action Stage & $n$ & $\mathrm{R}^{2}$ & Intercept & Beta & P-value & t Stat \\
\hline Northern Region & Flood & 4 & 0.81 & -0.40 & 0.02 & 0.10 & 2.90 \\
\hline Western Region & Drought & 6 & 0.25 & 0.04 & -0.03 & 0.31 & -1.17 \\
\hline *Wabash Region & Drought & 6 & 0.68 & -0.10 & 0.01 & 0.04 & 2.89 \\
\hline Wabash Region & Flood & 4 & 0.29 & -0.10 & 0.00 & 0.46 & 0.90 \\
\hline Wabash Region $^{2}$ & Flood & 7 & 0.22 & 0.39 & 0.00 & 0.29 & -1.18 \\
\hline *Wabash Region ${ }^{2}$ & Drought & 8 & 0.54 & -0.29 & 0.03 & 0.04 & 2.65 \\
\hline Wabash Region $^{3}$ & Flood & 5 & 0.07 & 0.18 & 0.00 & 0.67 & -0.47 \\
\hline West Southwest Region & Drought & 6 & 0.05 & 0.03 & -0.01 & 0.67 & -0.46 \\
\hline West Southwest Region & Flood & 12 & 0.02 & 0.18 & 0.00 & 0.63 & -0.49 \\
\hline West Southwest Region ${ }^{2}$ & Drought & 11 & 0.03 & 0.09 & 0.00 & 0.64 & -0.49 \\
\hline Little Egypt Region & Drought & 7 & 0.08 & 0.16 & 0.00 & 0.54 & -0.66 \\
\hline *Little Egypt Region & Flood & 12 & 0.59 & 1.11 & -0.02 & 0.00 & -3.76 \\
\hline Little Egypt Region ${ }^{2}$ & Drought & 9 & 0.05 & 0.24 & 0.00 & 0.55 & -0.62 \\
\hline
\end{tabular}

Table 8

2011 River Stage: Soy

\begin{tabular}{|c|c|c|c|c|c|c|c|}
\hline Observation Region & Action Stage & $\mathrm{n}$ & $\mathrm{R}^{2}$ & Intercept & Beta & P-value & $t$ Stat \\
\hline Northern Region & Flood & 4 & 0.55 & -0.49 & 0.02 & 0.26 & 1.56 \\
\hline Western Region & Drought & 6 & 0.41 & 0.53 & -0.19 & 0.17 & -1.68 \\
\hline *Wabash Region & Drought & 6 & 0.61 & -0.16 & 0.02 & 0.07 & 2.48 \\
\hline *Wabash Region & Flood & 4 & 0.98 & 0.22 & 0.00 & 0.01 & -9.36 \\
\hline Wabash Region $^{2}$ & Flood & 7 & 0.14 & 0.18 & 0.00 & 0.41 & -0.91 \\
\hline Wabash Region $^{2}$ & Drought & 7 & 0.05 & -0.27 & 0.01 & 0.58 & 0.59 \\
\hline Wabash Region $^{3}$ & Flood & 5 & 0.03 & 0.02 & 0.00 & 0.77 & 0.32 \\
\hline *West Southwest Region & Drought & 6 & 0.54 & 0.31 & -0.02 & 0.10 & -2.17 \\
\hline *West Southwest Region & Flood & 13 & 0.31 & 0.55 & -0.02 & 0.05 & -2.24 \\
\hline West Southwest Region $^{2}$ & Drought & 11 & 0.27 & -0.02 & 0.02 & 0.10 & 1.85 \\
\hline Little Egypt Region $^{\text {Wittle Egypt Region }}$ & Drought & 7 & 0.19 & 0.32 & -0.01 & 0.34 & -1.07 \\
\hline Little Egypt Region $^{2}$ & Flood & 12 & 0.10 & -0.21 & 0.01 & 0.32 & 1.06 \\
\hline
\end{tabular}


Table 9

2012 River Stage: Corn

\begin{tabular}{|c|c|c|c|c|c|c|c|}
\hline Observation Region & Action Stage & $n$ & $R^{2}$ & Intercept & Beta & P-value & t Stat \\
\hline Northern Region & Drought & 14 & 0.10 & -0.37 & 0.07 & 0.27 & 1.15 \\
\hline Western Region & Drought & 14 & 0.09 & -0.36 & 0.07 & 0.29 & 1.11 \\
\hline South Central Region & Drought & 12 & 0.10 & 0.08 & -0.02 & 0.33 & -1.03 \\
\hline Wabash Region & Drought & 5 & 0.05 & 0.18 & 0.00 & 0.72 & -0.39 \\
\hline Wabash Region $^{2}$ & Drought & 8 & 0.19 & 1.62 & -0.09 & 0.28 & -1.18 \\
\hline Wabash Region $^{3}$ & Drought & 11 & 0.08 & 0.23 & -0.01 & 0.41 & -0.87 \\
\hline West Southwest Region & Drought & 5 & 0.17 & 0.12 & -0.01 & 0.49 & -0.78 \\
\hline West Southwest Region ${ }^{2}$ & Drought & 5 & 0.16 & 0.04 & 0.00 & 0.51 & 0.74 \\
\hline West Southwest Region ${ }^{3}$ & Drought & 4 & 0.08 & -0.06 & 0.01 & 0.71 & 0.42 \\
\hline *West Southwest Region ${ }^{4}$ & Drought & 14 & 0.30 & -0.04 & -0.05 & 0.04 & -2.29 \\
\hline *Little Egypt Region & Drought & 4 & 0.94 & 0.48 & -0.02 & 0.03 & -5.78 \\
\hline Little Egypt Region $^{2}$ & Drought & 7 & 0.19 & 0.63 & -0.03 & 0.33 & -1.07 \\
\hline Little Egypt Region ${ }^{3}$ & Drought & 14 & 0.01 & 0.15 & 0.00 & 0.70 & -0.39 \\
\hline
\end{tabular}

Table 10

2012 River Stage: Soy

\begin{tabular}{|c|c|c|c|c|c|c|c|}
\hline Observation Region & Action Stage & $\mathrm{n}$ & $\mathrm{R}^{2}$ & Intercept & Beta & P-value & t Stat \\
\hline Northern Region & Drought & 13 & 0.01 & -0.23 & 0.02 & 0.74 & 0.35 \\
\hline Western Region & Drought & 13 & 0.03 & -0.41 & 0.09 & 0.57 & 0.58 \\
\hline South Central Region & Drought & 11 & 0.15 & 0.09 & -0.03 & 0.25 & -1.24 \\
\hline Wabash Region & Drought & 5 & 0.00 & 0.07 & 0.00 & 0.93 & -0.09 \\
\hline Wabash Region $^{2}$ & Drought & 8 & 0.20 & -0.93 & 0.06 & 0.27 & 1.22 \\
\hline Wabash Region $^{3}$ & Drought & 10 & 0.04 & 0.28 & -0.02 & 0.57 & -0.59 \\
\hline West Southwest Region & Drought & 5 & 0.50 & 0.31 & -0.02 & 0.18 & -1.72 \\
\hline West Southwest Region ${ }^{2}$ & Drought & 5 & 0.31 & 0.24 & -0.01 & 0.33 & -1.17 \\
\hline West Southwest Region $^{3}$ & Drought & 4 & 0.12 & 0.28 & -0.02 & 0.65 & -0.52 \\
\hline *West Southwest Region ${ }^{4}$ & Drought & 13 & 0.46 & 0.15 & -0.05 & 0.01 & -3.05 \\
\hline Little Egypt Region & Drought & 4 & 0.42 & 0.24 & 0.00 & 0.35 & -1.21 \\
\hline Little Egypt Region $^{2}$ & Drought & 7 & 0.11 & 0.43 & -0.02 & 0.47 & -0.78 \\
\hline Little Egypt Region ${ }^{3}$ & Drought & 13 & 0.08 & 0.28 & -0.03 & 0.34 & -1.00 \\
\hline
\end{tabular}




\section{Barge Rates}

A total of 100 simple linear regressions were conducted with 19 regressions displaying significance between barge rates and basis level movements. Much like the river stage regressions, the significant barge rate regressions occurred during drought and flood years in the Northern, Western, Wabash, West/Southwest and Little Egypt regions of Illinois. The number of significant regressions in the following tables showed higher correlation between barge rates and basis level movements. This is based on existing knowledge that transportation costs have $\mathrm{n}$ influence on basis movements.

The significant regressions showed that during both drought and flood occurrences, as barge freight traded at a premium, or trended higher, basis levels weakened in each region when compared to the designated control region. When barge freight traded at a premium, river facilities weakened their basis and were no longer willing to pay a premium for bushels with the already firming freight market. There were 5 regressions that illustrated as barge freight firmed, basis levels in the experimental region strengthened compared to the control region. The barge freight market is greatly influenced by river conditions during these drought and flood stages. Low river stages and high river stages present substantial risk to barge movement and loading, causing barge freight premiums to emerge in the market. Results showed basis levels firm towards interior Illinois markets as rivers became less navigable and barge freight increased. For example, interior shuttle-loading facilities who can reach export markets issued a premium in basis to pull bushels away from the river terminals when barge loading and transport became an issue. 
Table 11

1988 Barge Rate: Corn

\begin{tabular}{|c|c|c|c|c|c|c|c|}
\hline Observation Region & Action Stage & $\mathrm{n}$ & $\mathrm{R}^{2}$ & Intercept & Beta & P-value & $\mathrm{t}$ Stat \\
\hline Northern Region & Drought & 6 & 0.41 & -0.02 & 0.00 & 0.17 & -1.67 \\
\hline Northern Region $^{2}$ & Drought & 12 & 0.03 & -0.04 & 0.00 & 0.61 & -0.53 \\
\hline Western Region & Drought & 5 & 0.16 & -0.01 & 0.00 & 0.51 & -0.75 \\
\hline Western Region $^{2}$ & Drought & 12 & 0.04 & 0.01 & 0.00 & 0.52 & -0.66 \\
\hline South Central Region & Drought & 4 & 0.00 & 0.05 & 0.00 & 0.95 & -0.07 \\
\hline West Southwest Region $^{2}$ & Drought & 9 & 0.38 & -0.01 & 0.00 & 0.08 & -2.09 \\
\hline West Southwest Region $^{2}$ & Drought & 13 & 0.04 & 0.00 & 0.00 & 0.52 & -0.67 \\
\hline Little Egypt Region $^{2}$ & Drought & 10 & 0.32 & 0.07 & 0.00 & 0.09 & 1.93 \\
\hline Little Egypt Region $^{2}$ & Drought & 13 & 0.14 & 0.16 & 0.00 & 0.21 & -1.34 \\
\hline
\end{tabular}

Table 12

1988 Barge Rate: Soy

\begin{tabular}{|c|c|c|c|c|c|c|c|}
\hline Observation Region & Action Stage & $\mathrm{n}$ & $\mathrm{R}^{2}$ & Intercept & Beta & P-value & t Stat \\
\hline Northern Region & Drought & 6 & 0.00 & -0.10 & 0.00 & 0.99 & -0.01 \\
\hline *Northern Region ${ }^{2}$ & Drought & 12 & 0.53 & 0.19 & 0.00 & 0.01 & -3.33 \\
\hline Western Region & Drought & 5 & 0.44 & 0.01 & 0.00 & 0.23 & -1.52 \\
\hline${ }^{*}$ Western Region ${ }^{2}$ & Drought & 12 & 0.53 & 0.29 & 0.00 & 0.01 & -3.39 \\
\hline South Central Region & Drought & 4 & 0.12 & 0.04 & 0.00 & 0.66 & 0.52 \\
\hline *West Southwest Region & Drought & 9 & 0.49 & -0.02 & 0.00 & 0.04 & 2.60 \\
\hline West Southwest Region ${ }^{2}$ & Drought & 13 & 0.28 & 0.12 & 0.00 & 0.07 & -2.04 \\
\hline *Little Egypt Region & Drought & 10 & 0.57 & 0.03 & 0.00 & 0.01 & 3.28 \\
\hline Little Egypt Region $^{2}$ & Drought & 13 & 0.15 & 0.10 & 0.00 & 0.19 & -1.39 \\
\hline
\end{tabular}

Table 13

1993 Barge Rate: Corn

\begin{tabular}{|c|c|c|c|c|c|c|c|}
\hline Observation Region & Action Stage & $\mathrm{n}$ & $\mathrm{R}^{2}$ & Intercept & Beta & P-value & $\mathrm{t}$ Stat \\
\hline Western Region & Flood & 6 & 0.00 & -0.03 & 0.00 & 0.96 & 0.05 \\
\hline Western Region $^{2}$ & Flood & 5 & 0.62 & 0.00 & 0.00 & 0.11 & -2.22 \\
\hline West Southwest Region $^{2}$ & Flood & 8 & 0.01 & -0.01 & 0.00 & 0.85 & 0.19 \\
\hline West Southwest Region $^{2}$ & Flood & 5 & 0.07 & 0.01 & 0.00 & 0.66 & 0.49 \\
\hline Little Egypt Region & Flood & 7 & 0.26 & 0.11 & 0.00 & 0.24 & -1.34 \\
\hline
\end{tabular}


Table 14

1993 Barge Rate: Soy

\begin{tabular}{|c|c|c|c|c|c|c|c|}
\hline Observation Region & Action Stage & $\mathrm{n}$ & $\mathrm{R}^{2}$ & Intercept & Beta & P-value & t Stat \\
\hline Western Region & Flood & 6 & 0.16 & 0.01 & 0.00 & 0.44 & -0.87 \\
\hline${ }^{*}$ Western Region ${ }^{2}$ & Flood & 5 & 0.82 & 0.04 & 0.00 & 0.03 & -3.72 \\
\hline West Southwest Region & Flood & 8 & 0.01 & 0.00 & 0.00 & 0.84 & 0.21 \\
\hline West Southwest Region ${ }^{2}$ & Flood & 5 & 0.02 & 0.02 & 0.00 & 0.80 & -0.27 \\
\hline *Little Egypt Region & Flood & 7 & 0.85 & 0.09 & 0.00 & 0.00 & -5.26 \\
\hline
\end{tabular}

Table 15

2008 Barge Rate: Corn

\begin{tabular}{|c|c|c|c|c|c|c|c|}
\hline Observation Region & Action Stage & $\mathrm{n}$ & $\mathrm{R}^{2}$ & Intercept & Beta & P-value & t Stat \\
\hline Northern Region & Drought & 9 & 0.18 & 0.14 & 0.00 & 0.26 & -1.24 \\
\hline Western Region & Flood & 5 & 0.42 & -0.46 & 0.00 & 0.23 & 1.48 \\
\hline${ }^{*}$ Western Region ${ }^{2}$ & Flood & 5 & 0.89 & 0.15 & 0.00 & 0.02 & -4.86 \\
\hline Wabash Region & Flood & 7 & 0.11 & 0.22 & 0.00 & 0.48 & -0.77 \\
\hline *Wabash Region & Drought & 3 & 0.95 & 0.43 & 0.00 & 0.15 & -4.20 \\
\hline *Wabash Region ${ }^{2}$ & Drought & 13 & 0.55 & 0.10 & 0.00 & 0.00 & -3.67 \\
\hline West Southwest Region & Flood & 17 & 0.14 & 0.09 & 0.00 & 0.13 & -1.59 \\
\hline West Southwest Region & Drought & 5 & 0.85 & 0.01 & 0.00 & 0.03 & -4.17 \\
\hline Little Egypt Region & Flood & 10 & 0.13 & 0.24 & 0.00 & 0.30 & -1.12 \\
\hline Little Egypt Region ${ }^{2}$ & Flood & 5 & 0.51 & 0.36 & 0.00 & 0.18 & -1.76 \\
\hline Little Egypt Region & Drought & 5 & 0.63 & 0.14 & 0.00 & 0.11 & -2.26 \\
\hline
\end{tabular}


Table 16

2008 Barge Rate: Soy

\begin{tabular}{|c|c|c|c|c|c|c|c|}
\hline Observation Region & Action Stage & $\mathrm{n}$ & $\mathrm{R}^{2}$ & Intercept & Beta & P-value & t Stat \\
\hline Northern Region & Drought & 9 & 0.00 & -0.22 & 0.00 & 0.91 & 0.12 \\
\hline Western Region & Flood & 5 & 0.21 & -0.92 & 0.00 & 0.44 & 0.89 \\
\hline Western Region $^{2}$ & Flood & 5 & 0.37 & -0.58 & 0.00 & 0.28 & 1.32 \\
\hline Wabash Region & Flood & 7 & 0.02 & -0.08 & 0.00 & 0.78 & 0.30 \\
\hline *Wabash Region & Drought & 3 & 0.99 & 0.89 & 0.00 & 0.05 & -12.07 \\
\hline Wabash Region $^{2}$ & Drought & 13 & 0.24 & 0.14 & 0.00 & 0.09 & -1.88 \\
\hline West Southwest Region & Flood & 17 & 0.23 & 0.28 & 0.00 & 0.05 & -2.12 \\
\hline *West Southwest Region & Drought & 5 & 0.93 & 0.24 & 0.00 & 0.01 & -6.42 \\
\hline Little Egypt Region & Flood & 10 & 0.20 & -0.35 & 0.00 & 0.20 & 1.40 \\
\hline *Little Egypt Region ${ }^{2}$ & Flood & 5 & 0.80 & 0.49 & 0.00 & 0.04 & -3.51 \\
\hline * Little Egypt Region & Drought & 5 & 0.87 & 0.18 & 0.00 & 0.02 & -4.41 \\
\hline
\end{tabular}

Table 17

2011 Barge Rate: Corn

\begin{tabular}{|c|c|c|c|c|c|c|c|}
\hline Observation Region & Action Stage & $n$ & $R^{2}$ & Intercept & Beta & P-value & t Stat \\
\hline Western Region & Drought & 6 & 0.04 & 0.02 & 0.00 & 0.72 & -0.38 \\
\hline Wabash Region & Flood & 4 & 0.37 & -0.15 & 0.00 & 0.39 & 1.08 \\
\hline Wabash Region $^{2}$ & Flood & 6 & 0.11 & -0.39 & 0.00 & 0.52 & 0.70 \\
\hline Wabash Region & Drought & 6 & 0.68 & 0.58 & 0.00 & 0.01 & -3.59 \\
\hline Wabash Region $^{3}$ & Flood & 5 & 0.07 & 0.00 & 0.00 & 0.66 & 0.49 \\
\hline Wabash Region $^{2}$ & Drought & 8 & 0.17 & -0.03 & 0.00 & 0.41 & 0.91 \\
\hline *West Southwest Region & Drought & 6 & 0.89 & -0.48 & 0.00 & 0.00 & 5.69 \\
\hline West Southwest Region & Flood & 13 & 0.14 & 0.54 & 0.00 & 0.22 & -1.31 \\
\hline West Southwest Region ${ }^{2}$ & Drought & 11 & 0.07 & -0.01 & 0.00 & 0.44 & 0.80 \\
\hline Little Egypt Region & Drought & 7 & 0.39 & -0.04 & 0.00 & 0.14 & 1.78 \\
\hline Little Egypt Region & Flood & 12 & 0.21 & -0.63 & 0.00 & 0.14 & 1.61 \\
\hline Little Egypt Region ${ }^{2}$ & Drought & 9 & 0.31 & 0.37 & 0.00 & 0.12 & -1.76 \\
\hline
\end{tabular}


Table 18

2011 Barge Rate: Soy

\begin{tabular}{|c|c|c|c|c|c|c|c|}
\hline Observation Region & Action Stage & $\mathrm{n}$ & $\mathrm{R}^{2}$ & Intercept & Beta & P-value & t Stat \\
\hline *Western Region & Drought & 6 & 0.66 & 1.59 & 0.00 & 0.05 & -2.82 \\
\hline *Wabash Region & Flood & 4 & 0.85 & 0.22 & 0.00 & 0.08 & -3.36 \\
\hline Wabash Region $^{2}$ & Flood & 6 & 0.02 & 0.11 & 0.00 & 0.82 & 0.25 \\
\hline Wabash Region & Drought & 6 & 0.18 & -0.09 & 0.00 & 0.40 & 0.95 \\
\hline Wabash Region $^{3}$ & Flood & 5 & 0.13 & 0.42 & 0.00 & 0.55 & -0.68 \\
\hline Wabash Region $^{2}$ & Drought & 8 & 0.24 & 0.44 & 0.00 & 0.22 & -1.38 \\
\hline West Southwest Region & Drought & 6 & 0.25 & -0.11 & 0.00 & 0.31 & 1.16 \\
\hline *West Southwest Region & Flood & 13 & 0.60 & 1.20 & 0.00 & 0.00 & -4.07 \\
\hline West Southwest Region ${ }^{2}$ & Drought & 11 & 0.43 & 0.37 & 0.00 & 0.03 & -2.62 \\
\hline Little Egypt Region & Drought & 7 & 0.20 & 0.04 & 0.00 & 0.32 & 1.10 \\
\hline *Little Egypt Region & Flood & 12 & 0.49 & 1.09 & 0.00 & 0.01 & -3.09 \\
\hline Little Egypt Region $^{2}$ & Drought & 9 & 0.30 & 0.33 & 0.00 & 0.13 & -1.74 \\
\hline
\end{tabular}

Table 19

2012 Barge Rate: Corn

\begin{tabular}{|c|c|c|c|c|c|c|c|}
\hline Observation Region & Action Stage & $\mathrm{n}$ & $R^{2}$ & Intercept & Beta & P-value & t Stat \\
\hline Northern Region & Drought & 10 & 0.05 & 0.03 & 0.00 & 0.53 & -0.65 \\
\hline Western Region & Drought & 10 & 0.32 & 0.27 & 0.00 & 0.09 & -1.93 \\
\hline South Central Region & Drought & 12 & 0.07 & 0.12 & 0.00 & 0.40 & -0.88 \\
\hline Wabash Region & Drought & 5 & 0.27 & -0.31 & 0.00 & 0.37 & 1.05 \\
\hline Wabash Region $^{2}$ & Drought & 8 & 0.04 & 0.63 & 0.00 & 0.62 & -0.53 \\
\hline Wabash Region $^{3}$ & Drought & 11 & 0.09 & 0.19 & 0.00 & 0.37 & -0.94 \\
\hline West Southwest Region & Drought & 5 & 0.01 & 0.05 & 0.00 & 0.85 & 0.20 \\
\hline West Southwest Region ${ }^{2}$ & Drought & 5 & 0.01 & 0.10 & 0.00 & 0.87 & -0.17 \\
\hline West Southwest Region ${ }^{3}$ & Drought & 4 & 0.20 & -0.08 & 0.00 & 0.55 & 0.71 \\
\hline West Southwest Region ${ }^{4}$ & Drought & 14 & 0.01 & -0.18 & 0.00 & 0.81 & 0.25 \\
\hline Little Egypt Region & Drought & 4 & 0.63 & -0.12 & 0.00 & 0.21 & 1.84 \\
\hline Little Egypt Region $^{2}$ & Drought & 7 & 0.05 & 0.30 & 0.00 & 0.65 & -0.49 \\
\hline Little Egypt Region $^{3}$ & Drought & 14 & 0.37 & 0.42 & 0.00 & 0.02 & -2.66 \\
\hline
\end{tabular}


Table 20

2012 Barge Rate: Soy

\begin{tabular}{|c|c|c|c|c|c|c|c|}
\hline Observation Region & Action Stage & $\mathrm{n}$ & $\mathrm{R}^{2}$ & Intercept & Beta & P-value & t Stat \\
\hline Northern Region & Drought & 9 & 0.05 & -0.24 & 0.00 & 0.55 & 0.63 \\
\hline Western Region & Drought & 9 & 0.50 & 1.08 & 0.00 & 0.03 & -2.65 \\
\hline South Central Region & Drought & 11 & 0.14 & -0.16 & 0.00 & 0.26 & 1.21 \\
\hline Wabash Region & Drought & 5 & 0.60 & -0.88 & 0.00 & 0.12 & 2.14 \\
\hline Wabash Region $^{2}$ & Drought & 8 & 0.12 & -0.45 & 0.00 & 0.40 & 0.90 \\
\hline Wabash Region $^{3}$ & Drought & 10 & 0.21 & 0.43 & 0.43 & 0.18 & -1.46 \\
\hline West Southwest Region & Drought & 5 & 0.06 & 0.09 & 0.00 & 0.68 & 0.45 \\
\hline West Southwest Region $^{2}$ & Drought & 5 & 0.24 & 0.04 & 0.00 & 0.41 & 0.96 \\
\hline *West Southwest Region ${ }^{3}$ & Drought & 4 & 0.86 & -0.19 & 0.00 & 0.07 & 3.48 \\
\hline West Southwest Region ${ }^{4}$ & Drought & 13 & 0.43 & 0.67 & 0.00 & 0.02 & -2.87 \\
\hline Little Egypt Region & Drought & 4 & 0.33 & 0.12 & 0.00 & 0.43 & 0.98 \\
\hline Little Egypt Region $^{2}$ & Drought & 7 & 0.46 & -0.21 & 0.00 & 0.10 & 2.05 \\
\hline Little Egypt Region $^{3}$ & Drought & 13 & 0.25 & 0.76 & 0.00 & 0.08 & -1.91 \\
\hline
\end{tabular}

\section{Multiple Regressions}

The results of the multiple regressions using barge rates and river stages are shown below on Tables 21-30. 98 multiple regressions were performed with 17 showing significance.

These multiple regressions are divided by year, commodity, and each regression will denote which action stage, drought (D) or flood (F), the observations took place. Number of observations is represented by $(n)$ and one observation represents one week. Tables include an $R^{2}$ value, beta coefficients (B) and (B2), p-value (P and P2), and each t-statistic (tS and tS2). Analysis design implemented barge rates as the first variable and river stage as the second variable. The 17 significant multiple regressions tell us that when combining both barge rate and river stages in a multiple regression we cannot account for more variations in grain basis. 
Table 21

1988 Multiple: Corn

\begin{tabular}{|c|c|c|c|c|c|c|c|c|c|c|}
\hline Observation Region & Stage & $\mathrm{n}$ & $\mathrm{R}^{2}$ & $\mathrm{Int}$ & $\mathrm{B}$ & $\mathrm{P}$ & $\mathrm{tS}$ & $\mathrm{B}^{2}$ & $\mathrm{P}^{2}$ & $\mathrm{tS}^{2}$ \\
\hline Northern Region & $\mathrm{D}$ & 6 & 0.41 & -0.01 & 0.00 & 0.39 & -1.00 & 0.00 & 0.96 & $\begin{array}{c}- \\
0.06\end{array}$ \\
\hline Northern Region $^{2}$ & $\mathrm{D}$ & 12 & 0.03 & -0.05 & 0.00 & 0.73 & -0.35 & 0.00 & 0.97 & 0.04 \\
\hline Western Region $^{\text {Western Region }}{ }^{2}$ & $\mathrm{D}$ & 5 & 0.96 & -0.10 & 0.00 & 0.36 & -1.18 & 0.03 & 0.25 & 1.62 \\
\hline $\begin{array}{c}\text { South Central } \\
\text { Region }\end{array}$ & $\mathrm{D}$ & 4 & 0.94 & 0.32 & 0.00 & 0.55 & 0.86 & -0.12 & 0.16 & - \\
\hline $\begin{array}{c}\text { West Southwest } \\
\text { Region }\end{array}$ & $\mathrm{D}$ & 9 & 0.44 & -0.03 & 0.00 & 0.07 & 2.16 & 0.00 & 0.25 & 1.29 \\
\hline $\begin{array}{c}\text { West Southwest } \\
\text { Region }\end{array}$ & $\mathrm{D}$ & 13 & 0.18 & 0.07 & 0.00 & 0.19 & -1.41 & -0.01 & 0.22 & - \\
\hline $\begin{array}{c}* \\
\text { Little Egypt Region }\end{array}$ & $\mathrm{D}$ & 10 & 0.91 & 0.16 & 0.00 & 0.12 & 1.77 & -0.01 & 0.00 & - \\
\hline $\begin{array}{c}\text { Little Egypt Region } \\
2\end{array}$ & $\mathrm{D}$ & 13 & 0.22 & 0.26 & 0.00 & 0.14 & -1.63 & -0.01 & 0.35 & $\begin{array}{c}- \\
0.98\end{array}$ \\
\hline
\end{tabular}

Table 22

1988 Multiple: Soy

\begin{tabular}{|c|c|c|c|c|c|c|c|c|c|c|}
\hline Observation Region & Stage & $\mathrm{n}$ & $\mathrm{R}^{2}$ & $\mathrm{Int}$ & $\mathrm{B}$ & $\mathrm{P}$ & $\mathrm{tS}$ & $\mathrm{B}^{2}$ & $\mathrm{P}^{2}$ & $\mathrm{tS}^{2}$ \\
\hline Northern Region $^{2}$ & $\mathrm{D}$ & 6 & 0.00 & -0.13 & 0.00 & 0.98 & 0.03 & 0.01 & 0.97 & 0.05 \\
\hline Northern Region $^{2}$ & $\mathrm{D}$ & 12 & 0.57 & -0.09 & 0.00 & 0.09 & -1.88 & 0.04 & 0.34 & 1.01 \\
\hline Western Region & $\mathrm{D}$ & 5 & 0.59 & -0.33 & 0.00 & 0.86 & 0.19 & 0.08 & 0.47 & 0.88 \\
\hline *Western Region $^{2}$ & $\mathrm{D}$ & 12 & 0.56 & 0.13 & 0.00 & 0.05 & -2.28 & 0.04 & 0.52 & 0.67 \\
\hline $\begin{array}{c}\text { South Central } \\
\text { Region }\end{array}$ & $\mathrm{D}$ & 4 & 0.96 & -0.23 & 0.00 & 0.47 & -1.09 & 0.14 & 0.14 & 4.42 \\
\hline $\begin{array}{c}* \text { West Southwest } \\
\text { Region }\end{array}$ & $\mathrm{D}$ & 9 & 0.83 & -0.06 & 0.00 & $0.00 *$ & 5.42 & 0.00 & 0.01 & 3.47 \\
\hline $\begin{array}{c}\text { West Southwest } \\
\text { Region }\end{array}$ & $\mathrm{D}$ & 13 & 0.29 & 0.09 & 0.00 & 0.28 & -1.13 & 0.00 & 0.67 & 0.43 \\
\hline $\begin{array}{c}\text { Little Egypt Region } \\
\text { Wittle Egypt Region }\end{array}$ & $\mathrm{D}$ & 10 & 0.63 & 0.09 & 0.00 & 0.07 & 2.14 & 0.00 & 0.36 & - \\
\hline $\begin{array}{c}\text { L }^{2} \\
\text { W }\end{array}$ & 13 & 0.15 & 0.08 & 0.00 & 0.45 & -0.78 & 0.00 & 0.87 & 0.16 \\
\hline
\end{tabular}


Table 23

1993 Multiple: Corn

\begin{tabular}{|c|c|c|c|c|c|c|c|c|c|c|}
\hline Observation Region & Stage & $\mathrm{n}$ & $\mathrm{R}^{2}$ & Int & B & $\mathrm{P}$ & tS & $B^{2}$ & $P^{2}$ & $\mathrm{tS}^{2}$ \\
\hline Western Region & $\mathrm{F}$ & 6 & 0.40 & -0.04 & 0.00 & 0.40 & -0.97 & 0.00 & 0.25 & 1.41 \\
\hline *Western Region ${ }^{2}$ & $\mathrm{~F}$ & 5 & 0.98 & -0.05 & 0.00 & 0.01 & -10.1 & 0.01 & 0.02 & 6.86 \\
\hline $\begin{array}{c}\text { West Southwest } \\
\text { Region }\end{array}$ & $\mathrm{F}$ & 8 & 0.02 & 0.01 & 0.00 & 0.88 & 0.16 & 0.00 & 0.80 & $\begin{array}{c}- \\
0.27 \\
\end{array}$ \\
\hline $\begin{array}{c}\text { West Southwest } \\
\text { Region }^{2}\end{array}$ & $\mathrm{~F}$ & 5 & 0.15 & 0.01 & 0.00 & 0.62 & 0.57 & 0.00 & 0.71 & $\begin{array}{c}- \\
0.43 \\
\end{array}$ \\
\hline Little Egypt Region & $\mathrm{F}$ & 7 & 0.28 & 0.19 & 0.00 & 0.37 & -1.01 & 0.00 & 0.77 & $\begin{array}{c}- \\
0.31\end{array}$ \\
\hline
\end{tabular}

Table 24

1993 Multiple: Soy

\begin{tabular}{|c|c|c|c|c|c|c|c|c|c|c|}
\hline Observation Region & Stage & $\mathrm{n}$ & $\mathrm{R}^{2}$ & $\mathrm{Int}$ & $\mathrm{B}$ & $\mathrm{P}$ & $\mathrm{tS}$ & $\mathrm{B}^{2}$ & $\mathrm{P}^{2}$ & $\mathrm{tS}^{2}$ \\
\hline Western Region & $\mathrm{F}$ & 6 & 0.19 & 0.03 & 0.00 & 0.80 & -0.28 & 0.00 & 0.74 & $\begin{array}{c}- \\
0.37\end{array}$ \\
\hline Western Region $^{2}$ & $\mathrm{~F}$ & 5 & 0.86 & 0.01 & 0.00 & 0.16 & -2.20 & 0.00 & 0.52 & 0.78 \\
\hline $\begin{array}{c}\text { West Southwest } \\
\text { Region }\end{array}$ & $\mathrm{F}$ & 8 & 0.30 & 0.12 & 0.00 & 0.90 & 0.13 & 0.00 & 0.21 & - \\
\hline $\begin{array}{c}\text { West Southwest } \\
\text { Region }\end{array}$ & $\mathrm{F}$ & 5 & 0.15 & -0.01 & 0.00 & 0.61 & -0.60 & 0.00 & 0.64 & 0.55 \\
\hline *Little Egypt Region & $\mathrm{F}$ & 7 & 0.85 & 0.08 & 0.00 & 0.04 & -2.94 & 0.00 & 0.93 & 0.09 \\
\hline
\end{tabular}


Table 25

2008 Multiple: Corn

\begin{tabular}{|c|c|c|c|c|c|c|c|c|c|c|}
\hline Observation Region & Stage & $\mathrm{n}$ & $\mathrm{R}^{2}$ & $\mathrm{Int}$ & $\mathrm{B}$ & $\mathrm{P}$ & $\mathrm{tS}$ & $\mathrm{B}^{2}$ & $\mathrm{P}^{2}$ & $\mathrm{tS}^{2}$ \\
\hline Northern Region & $\mathrm{D}$ & 12 & 0.01 & -0.08 & 0.00 & 0.84 & -0.21 & 0.01 & 0.88 & 0.16 \\
\hline Western Region & $\mathrm{F}$ & 5 & 0.48 & -0.55 & 0.00 & 0.34 & 1.23 & 0.00 & 0.68 & 0.48 \\
\hline Western Region & $\mathrm{F}$ & 5 & 0.89 & 0.15 & 0.00 & 0.07 & -3.49 & 0.00 & 0.75 & 0.37 \\
\hline Wabash Region & $\mathrm{F}$ & 7 & 0.36 & 0.14 & 0.00 & 0.86 & 0.19 & 0.00 & 0.27 & - \\
\hline *Wabash Region & $\mathrm{D}$ & 13 & 0.67 & -0.44 & 0.00 & 0.01 & -3.29 & 0.03 & 0.09 & 1.89 \\
\hline $\begin{array}{c}\text { West Southwest } \\
\text { West Southwest }\end{array}$ & $\mathrm{F}$ & 17 & 0.19 & 0.17 & 0.00 & 0.53 & -0.64 & 0.00 & 0.41 & - \\
\hline $\begin{array}{c}\text { W } \\
\text { Wittle Egypt Region }\end{array}$ & $\mathrm{F}$ & 10 & 0.14 & 0.21 & 0.00 & 0.33 & -1.06 & 0.00 & 0.87 & 0.16 \\
\hline $\begin{array}{c}* \\
\text { Regittle Egypt }\end{array}$ & $\mathrm{F}$ & 5 & 0.98 & 0.63 & 0.00 & 0.15 & -2.28 & -0.01 & 0.02 & - \\
\hline $\begin{array}{c}\text { Little Egypt Region } \\
\text { W }\end{array}$ & $\mathrm{D}$ & 5 & 0.95 & 0.20 & 0.00 & 0.14 & -2.37 & -0.01 & 0.07 & $\begin{array}{c}- \\
3.68\end{array}$ \\
\hline
\end{tabular}

Table 26

2008 Multiple: Soy

\begin{tabular}{|c|c|c|c|c|c|c|c|c|c|c|}
\hline Observation Region & Stage & $\mathrm{n}$ & $\mathrm{R}^{2}$ & Int & B & $\mathrm{P}$ & tS & $B^{2}$ & $\mathrm{P}^{2}$ & $\mathrm{tS}^{2}$ \\
\hline Northern Region & D & 9 & 0.01 & -0.07 & 0.00 & 0.89 & 0.15 & -0.04 & 0.86 & $\begin{array}{c}- \\
0.19\end{array}$ \\
\hline Western Region & $\mathrm{F}$ & 5 & 0.60 & -0.12 & 0.00 & 0.37 & 1.15 & -0.05 & 0.30 & $\begin{array}{c}- \\
1.40\end{array}$ \\
\hline Western Region $^{2}$ & $\mathrm{~F}$ & 5 & 0.45 & -0.58 & 0.00 & 0.61 & 0.59 & 0.00 & 0.64 & 0.54 \\
\hline Wabash Region & $\mathrm{F}$ & 7 & 0.02 & -0.10 & 0.00 & 0.80 & 0.28 & 0.00 & 0.92 & $\begin{array}{c}- \\
0.11\end{array}$ \\
\hline Wabash Region & D & 13 & 0.29 & 0.59 & 0.00 & 0.07 & -2.02 & -0.03 & 0.43 & $\begin{array}{c}- \\
0.82\end{array}$ \\
\hline West Southwest & $\mathrm{F}$ & 17 & 0.23 & 0.30 & 0.00 & 0.16 & -1.50 & 0.00 & 0.93 & $\begin{array}{c}- \\
0.09\end{array}$ \\
\hline West Southwest & D & 5 & 0.94 & 0.29 & 0.00 & 0.05 & -4.44 & -0.01 & 0.58 & $\begin{array}{c}- \\
0.65\end{array}$ \\
\hline Little Egypt Region & $\mathrm{F}$ & 10 & 0.40 & -0.83 & 0.00 & 0.28 & 1.18 & 0.02 & 1.56 & 1.56 \\
\hline Little Egypt Region ${ }^{2}$ & $\mathrm{~F}$ & 5 & 0.90 & 0.30 & 0.00 & 0.06 & -4.03 & 0.01 & 0.32 & 1.33 \\
\hline Little Egypt Region ${ }^{2}$ & D & 5 & 0.94 & 0.38 & 0.00 & 0.06 & -3.78 & -0.02 & 0.24 & $\begin{array}{c}- \\
1.64\end{array}$ \\
\hline
\end{tabular}


Table 27

2011 Multiple: Corn

\begin{tabular}{|c|c|c|c|c|c|c|c|c|c|c|}
\hline Observation Region & Stage & $n$ & $\mathrm{R}^{2}$ & Int & B & $P$ & tS & $\mathrm{B}^{2}$ & $P^{2}$ & $\mathrm{tS}^{2}$ \\
\hline Western Region & $\mathrm{D}$ & 6 & 0.26 & 0.08 & 0.00 & 0.88 & -0.17 & -0.03 & 0.41 & 0.96 \\
\hline *Wabash Region & $\mathrm{D}$ & 6 & 0.86 & -0.27 & 0.00 & 0.15 & 1.95 & 0.01 & 0.03 & 3.80 \\
\hline Wabash Region & $\mathrm{F}$ & 4 & -0.16 & -0.16 & 0.00 & 0.77 & 0.38 & 0.00 & 0.92 & $\begin{array}{c}- \\
0.12\end{array}$ \\
\hline Wabash Region $^{2}$ & $\mathrm{~F}$ & 6 & 0.26 & 5.53 & -0.01 & 0.55 & -0.68 & -0.03 & 0.49 & $\begin{array}{c}- \\
0.78\end{array}$ \\
\hline Wabash Region ${ }^{2}$ & $\mathrm{D}$ & 8 & 0.79 & 0.23 & 0.00 & 0.06 & -2.44 & 0.01 & 0.17 & 1.60 \\
\hline Wabash Region ${ }^{3}$ & $\mathrm{~F}$ & 5 & 0.48 & -0.10 & 0.00 & 0.34 & 1.25 & -0.01 & 0.34 & $\begin{array}{c}- \\
1.24 \\
\end{array}$ \\
\hline $\begin{array}{l}\text { *West Southwest } \\
\text { Region }\end{array}$ & $\mathrm{D}$ & 6 & 0.98 & -0.42 & 0.00 & 0.00 & 11.36 & -0.01 & 0.04 & $\begin{array}{c}- \\
3.51\end{array}$ \\
\hline $\begin{array}{c}\text { West Southwest } \\
\text { Region }\end{array}$ & $\mathrm{F}$ & 13 & 0.14 & 0.58 & 0.00 & 0.26 & -1.18 & 0.00 & 0.80 & $\begin{array}{c}- \\
0.27 \\
\end{array}$ \\
\hline $\begin{array}{c}\text { West Southwest } \\
\text { Region }^{2}\end{array}$ & $\mathrm{D}$ & 11 & 0.07 & -0.03 & 0.00 & 0.56 & 0.61 & 0.00 & 0.90 & 0.13 \\
\hline Little Egypt Region & $\mathrm{D}$ & 7 & 0.48 & -0.23 & 0.00 & 0.15 & 1.76 & 0.01 & 0.44 & 0.85 \\
\hline Little Egypt Region & $F$ & 12 & 0.60 & 0.78 & 0.00 & 0.59 & 0.56 & -0.02 & 0.02 & $\begin{array}{c}- \\
2.97\end{array}$ \\
\hline Little Egypt Region ${ }^{2}$ & $D$ & 9 & 0.39 & 0.44 & 0.00 & 0.12 & -1.81 & -0.01 & 0.41 & $\begin{array}{c}- \\
0.89\end{array}$ \\
\hline
\end{tabular}


Table 28

2011 Multiple: Soy

\begin{tabular}{|c|c|c|c|c|c|c|c|c|c|c|}
\hline Observation Region & Stage & $\mathrm{n}$ & $\mathrm{R}^{2}$ & Int & B & $P$ & tS & $B^{2}$ & $P^{2}$ & $\mathrm{tS}^{2}$ \\
\hline *Western Region & $\mathrm{D}$ & 6 & 0.90 & 1.88 & 0.00 & 0.03 & -3.77 & -0.15 & 0.08 & 2.62 \\
\hline Wabash Region & $\mathrm{D}$ & 6 & 0.80 & -0.40 & 0.00 & 0.19 & 1.70 & 0.02 & 0.06 & 3.04 \\
\hline Wabash Region & $\mathrm{F}$ & 4 & 0.98 & 0.22 & 0.00 & 0.92 & 0.13 & 0.00 & 0.25 & $\begin{array}{c}- \\
2.42\end{array}$ \\
\hline Wabash Region $^{2}$ & $\mathrm{~F}$ & 6 & 0.11 & 0.88 & 0.00 & 0.63 & -0.53 & 0.00 & 0.61 & $\begin{array}{c}- \\
0.57\end{array}$ \\
\hline Wabash Region $^{2}$ & $\mathrm{D}$ & 8 & 0.24 & 0.53 & 0.00 & 0.32 & -1.12 & 0.00 & 0.90 & $\begin{array}{c}- \\
0.13 \\
\end{array}$ \\
\hline Wabash Region $^{3}$ & $\mathrm{~F}$ & 5 & 0.51 & 0.25 & 0.00 & 0.30 & -1.40 & 0.00 & 0.34 & 1.24 \\
\hline $\begin{array}{l}\text { *West Southwest } \\
\text { Region }\end{array}$ & $\mathrm{D}$ & 6 & 0.86 & 0.04 & 0.00 & 0.08 & 2.57 & -0.02 & 0.04 & $\begin{array}{c}- \\
3.55\end{array}$ \\
\hline $\begin{array}{c}\text { *West Southwest } \\
\text { Region }\end{array}$ & $\mathrm{F}$ & 13 & 0.78 & 1.46 & 0.00 & 0.00 & -4.54 & -0.01 & 0.02 & $\begin{array}{c}- \\
2.79 \\
\end{array}$ \\
\hline $\begin{array}{c}\text { West Southwest } \\
\text { Region }^{2}\end{array}$ & $\mathrm{D}$ & 11 & 0.44 & 0.33 & 0.00 & 0.17 & -1.51 & 0.00 & 0.84 & 0.21 \\
\hline Little Egypt Region & $\mathrm{D}$ & 7 & 0.22 & 0.16 & 0.00 & 0.72 & 0.39 & -0.01 & 0.77 & $\begin{array}{c}- \\
0.32 \\
\end{array}$ \\
\hline Little Egypt Region & $\mathrm{F}$ & 12 & 0.49 & 1.10 & 0.00 & 0.03 & -2.61 & 0.00 & 0.99 & $\begin{array}{c}- \\
0.01\end{array}$ \\
\hline *Little Egypt & $\mathrm{D}$ & 9 & 0.75 & 0.71 & 0.00 & $0.02 *$ & -3.03 & -0.03 & $0.02 *$ & $\begin{array}{c}- \\
3.33 \\
\end{array}$ \\
\hline
\end{tabular}


Table 29

2012 Multiple: Corn

\begin{tabular}{|c|c|c|c|c|c|c|c|c|c|c|}
\hline Observation Region & Stage & $\mathrm{n}$ & $R^{2}$ & Int & B & $P$ & tS & $\mathrm{B}^{2}$ & $P^{2}$ & $\mathrm{tS}^{2}$ \\
\hline Northern Region & $\mathrm{D}$ & 10 & 0.23 & -0.66 & 0.00 & 0.79 & 0.28 & 0.11 & 0.24 & 1.30 \\
\hline Western Region & $\mathrm{D}$ & 10 & 0.39 & 0.03 & 0.00 & 0.12 & -1.78 & 0.08 & 0.38 & 0.94 \\
\hline $\begin{array}{l}\text { South Central } \\
\text { Region }\end{array}$ & $\mathrm{D}$ & 12 & 0.25 & 0.23 & 0.00 & 0.20 & -1.38 & -0.03 & 0.17 & $\begin{array}{c}- \\
1.49\end{array}$ \\
\hline Wabash Region & $\mathrm{D}$ & 5 & 0.61 & -0.54 & 0.00 & 0.23 & 1.70 & -0.01 & 0.32 & $\begin{array}{c}- \\
1.32\end{array}$ \\
\hline Wabash Region ${ }^{2}$ & $\mathrm{D}$ & 8 & 0.28 & 1.99 & 0.00 & 0.47 & 0.78 & -0.20 & 0.26 & $\begin{array}{c}- \\
1.26 \\
\end{array}$ \\
\hline Wabash Region ${ }^{2}$ & $\mathrm{D}$ & 11 & 0.17 & 0.31 & 0.00 & 0.38 & -0.94 & -0.01 & 0.41 & $\begin{array}{c}- \\
0.87\end{array}$ \\
\hline $\begin{array}{c}\text { West Southwest } \\
\text { Region }\end{array}$ & $\mathrm{D}$ & 5 & 0.22 & 0.08 & 0.00 & 0.75 & 0.36 & -0.01 & 0.54 & $\begin{array}{c}- \\
0.73 \\
\end{array}$ \\
\hline $\begin{array}{c}\text { West Southwest } \\
\text { Region }^{2}\end{array}$ & $\mathrm{D}$ & 5 & 0.34 & -0.15 & 0.00 & 0.54 & 0.74 & 0.01 & 0.43 & 0.99 \\
\hline $\begin{array}{c}\text { West Southwest } \\
\text { Region }^{3}\end{array}$ & $\mathrm{D}$ & 4 & 0.70 & -0.59 & 0.00 & 0.38 & 1.45 & 0.03 & 0.42 & 1.30 \\
\hline $\begin{array}{c}\text { West Southwest } \\
\text { Region }^{4}\end{array}$ & $\mathrm{D}$ & 14 & 0.38 & -0.31 & 0.00 & 0.27 & 1.17 & -0.05 & 0.03 & $\begin{array}{c}- \\
2.59 \\
\end{array}$ \\
\hline Little Egypt Region & $\mathrm{D}$ & 4 & 0.98 & 0.33 & 0.00 & 0.45 & 1.16 & -0.02 & 0.16 & $\begin{array}{c}- \\
3.81 \\
\end{array}$ \\
\hline Little Egypt Region² & $\mathrm{D}$ & 7 & 0.58 & 1.59 & 0.00 & 0.13 & -1.92 & -0.06 & 0.09 & $\begin{array}{c}- \\
2.24 \\
\end{array}$ \\
\hline $\begin{array}{l}* \text { Little Egypt } \\
\text { Region }^{3}\end{array}$ & D & 14 & 0.37 & 0.42 & 0.00 & 0.03 & -2.51 & 0.00 & 0.93 & $\begin{array}{c}- \\
0.09\end{array}$ \\
\hline
\end{tabular}


Table 30

2012 Multiple: Soy

\begin{tabular}{|c|c|c|c|c|c|c|c|c|c|c|}
\hline Observation Region & Stage & $n$ & $\mathrm{R}^{2}$ & Int & B & $P$ & tS & $\mathrm{B}^{2}$ & $P^{2}$ & $\mathrm{tS}^{2}$ \\
\hline Northern Region & $\mathrm{D}$ & 9 & 0.05 & -0.20 & 0.00 & 0.72 & 0.38 & -0.01 & 0.95 & $\begin{array}{c}- \\
0.06\end{array}$ \\
\hline *Western Region & $\mathrm{D}$ & 9 & 0.51 & 0.85 & 0.00 & 0.05 & -2.41 & 0.07 & 0.69 & 0.42 \\
\hline $\begin{array}{c}\text { South Central } \\
\text { Region }\end{array}$ & $\mathrm{D}$ & 11 & 0.22 & -0.06 & 0.00 & 0.42 & 0.84 & -0.02 & 0.40 & $\begin{array}{c}- \\
0.88 \\
\end{array}$ \\
\hline *Wabash Region & $D$ & 5 & 0.90 & -1.17 & 0.00 & 0.05 & 4.28 & -0.01 & 0.13 & 2.46 \\
\hline Wabash Region $^{2}$ & $\mathrm{D}$ & 8 & 0.20 & -0.98 & 0.00 & 0.87 & -0.17 & 0.08 & 0.50 & 0.73 \\
\hline Wabash Region $^{3}$ & $\mathrm{D}$ & 10 & 0.26 & 0.73 & 0.00 & 0.20 & -1.42 & -0.02 & 0.53 & $\begin{array}{c}- \\
0.66\end{array}$ \\
\hline $\begin{array}{l}\text { West Southwest } \\
\text { Region }\end{array}$ & D & 5 & 0.70 & 0.19 & 0.00 & 0.37 & 1.15 & -0.02 & 0.18 & $\begin{array}{c}- \\
2.04\end{array}$ \\
\hline $\begin{array}{c}\text { West Southwest } \\
\text { Region }^{2}\end{array}$ & D & 5 & 0.32 & 0.22 & 0.00 & 0.97 & 0.05 & -0.01 & 0.68 & $\begin{array}{c}- \\
0.48\end{array}$ \\
\hline $\begin{array}{c}\text { West Southwest } \\
\text { Region }^{3}\end{array}$ & $\mathrm{D}$ & 4 & 0.94 & -0.43 & 0.00 & 0.17 & 3.55 & 0.02 & 0.47 & 1.09 \\
\hline $\begin{array}{l}\text { *West Southwest } \\
\text { Region }{ }^{4}\end{array}$ & $\mathrm{D}$ & 13 & 0.65 & 0.55 & 0.00 & 0.04 & -2.31 & -0.04 & 0.03 & $\begin{array}{c}- \\
2.48\end{array}$ \\
\hline Little Egypt Region & $D$ & 4 & 0.45 & 0.20 & 0.00 & 0.85 & 0.24 & 0.00 & 0.71 & $\begin{array}{c}- \\
0.48\end{array}$ \\
\hline Little Egypt Region $^{2}$ & $\mathrm{D}$ & 7 & 0.47 & -0.41 & 0.00 & 0.17 & 1.66 & 0.01 & 0.75 & 0.34 \\
\hline Little Egypt Region $^{3}$ & D & 13 & 0.29 & 0.84 & 0.00 & 0.12 & -1.70 & -0.02 & 0.47 & $\begin{array}{c}- \\
0.75\end{array}$ \\
\hline
\end{tabular}




\section{CHAPTER V}

\section{CONCLUSIONS}

Basis remains a fundamental marketing tool for grain companies and respective participants. Understanding seasonal basis patterns and local or external factors that affect grain basis is valuable information for commodity traders, grain facility managers, and producers alike. While transportation costs, storage space, and transportation infrastructure have been shown to influence basis level movements it is uncertain whether or not other outside factors, such as river stages, contribute to these basis movements. During times of extreme drought or flood, grain transportation on our nation's rivers becomes a major concern. Barge draft restrictions become more stringent during times of drought and loading barges during times of flood becomes a safety concern. River stages have an effect on barge freight markets, causing fluctuations in freight rates during drought and flood periods. It was assumed that the combination of these two variables may account for variations in basis levels throughout regions of Illinois.

There has been a sufficient amount of research on the theory of basis and which factors are known to influence basis levels. Philip Garcia and Darrel Good (1983) originally identified basis to be a function of the theory of carrying charge but also identified three factors which affect basis. To begin with, the theory of carrying charge is the cost associated with storing a physical commodity over a defined period of time. The other three factors are storage costs, size 
of stocks, and grain flow magnitude, or rate of demand to market. Garcia and Good concluded that the relationship between these factors during harvest and post-harvest periods explain variations in basis in Illinois.

This study sought to contribute to prior research regarding the theory of basis and understanding local or external factors that explain basis level movements in the state of Illinois. Regression results did show that during drought and flood occurrences basis level movements are explained by river stages and barge rates on the Illinois, Mississippi, and Ohio Rivers. Significant regressions within the results show that basis levels relative to the designated control region both strengthen and weaken during drought and flood occurrences. The multiple regressions show that when combining the variables of river stages and barge rates one cannot account for a greater amount of variations in basis levels.

One implication in this study was the use of the North Central region as the control basis region. Although this region is insulated within the state of Illinois, it is still heavily dependent on river transportation via the Illinois River. As previously stated, this region was chosen because the stretch of the Illinois River which navigates through the region is more heavily regulated by locks and dams, providing less volatility of river stages when compared to the lower reaches of the Illinois River. Future research should consider utilizing a basis region that is nondependent on barge transportation, such as Nebraska or interior Indiana. These basis regions may provide a more "normal" basis and offer different results.

The second implication found during this study was the use of average region basis to designate experimental basis regions and control basis regions. The basis data used may have been skewed or misrepresented by taking the average basis for an entire region instead of using a precise grain terminal for basis data collection. Each region used in this study encompassed a 
large portion of Illinois. Some regions included processors and river terminals alike, offering a large degree of variation in basis levels. This study would have better accuracy if basis data was collected using a small group of grain terminals representing interior Illinois regions and river market regions. For example, one could use Decatur as a control basis and use St. Louis, Quincy, Havana, Davenport, Ottawa, or Cairo as river market basis. With volatile river stages, these basis locations may offer a clearer picture of what is occurring with basis during drought and flood years.

The final implication found during this study was the design of the multiple regression models. Although simple regressions did show that responses in river stages and barge rates are related to changes in basis, it is uncertain that combining these two variables would provide better explanation of basis movements. After performing initial analysis, correlation tests were performed and showed that river stages and barge rates were highly correlated. The high correlation between these two variables may have resulted in multicollinearity within the multiple regressions.

Since the idea of this study began during the drought of 2012, several areas of future research are of key interest. 1) How do environmental disturbances, such as Hurricane Katrina, affect Midwest basis level patterns? Another environmental disturbance that occurred last winter was icy conditions on the Illinois and Mississippi Rivers. Ice gorges plauged both rivers, busting barge fleets and preventing tugs from reaching the more Northern stretches of these rivers. 2) What affect will the Renewable Fuel Standard have on corn and soybean basis in the Midwest? 3) With evolving plant science techniques and genetically modified organisms, how will larger crop yields and grain inventories affect basis movements? 4) How will river navigability improvements affect the grain marketing channel of the Midwest? 5) How will new 
rail safety standards issued by the federal government change the dynamics of domestic

freight? Changing market conditions and market disruptions along with the effects they can have on commodity markets is worth further exploration. 


\section{REFERENCES}

Brown, D.M. "The Nation's Inland Waterway System and Rural America." Rural America 16(2002):11-17.

Dhuyvetter, Kevin. and Terry Kastens. "Forecasting Crop Basis: Practical Alternatives." NCR134 Conference on Applied Commodity Price Analysis, Forecasting, and Market Risk Management, Ed. T.C. Schroeder, Manhattan, Kansas: Kansas State University, Department of Agricultural Economics, 1998, pp. 49-67.

Farmdoc - Marketing\&Outlook. Farmdoc - Marketing\&Outlook. N.p., n.d. Web. 20 Nov. 2012

Garcia, P. and D.L. Good. "An Analysis of the Factors Influencing the Illinois Corn Basis, 19711981." NCR-134 Conference on Applied Commodity Price Analysis, Forecasting, and Market Risk Management, Ed. M. Hayenga, Ames, lowa: lowa State University, Department of Agricultural Economics, 1983, pp. 306-326.

Kahl, K.H. and C.E. Curtis, Jr. "A Comparative Analysis of the Corn Basis in Feed Grain Deficit and Surplus Areas." Review of Research in Futures Markets, 5:3(1986):220-232.

Lorton, S., \& White, D. (2010). The art of grain merchandising: Formerly the merchant's edge. Champaign, IL: Stipes Publishing Company.

Maass, Philip and Mark L. Waller. "Factors Affecting Texas Wheat Basis Behavior." Texas A\&M University, College Station, Texas.

Marathon, Nick, and Adam Sparger. Transportation of U.S. Grains A Modal Share Analysis 19782010 Update. Rep. N.p.: United States Department of Agriculture, n.d. Print.

Martin, L., J.L. Groenewegen, and E. Pidgeon. "Factors Affecting Corn Basis in Southwestern Ontario." American Journal of Agricultural Economics, 62:1(1980):107-112.

McKenzie A. The Effects of Barge Shocks on Soybean Basis Levels in Arkansas: A Study of Market Integration. Agribusiness [serial online]. Winter2005 2005,21(1):37-52. Available from: Business Source Complete, Ipswich, MA. Accessed February 5, 2013.

Naik, G. and R.M. Leuthold. "A Note on the Factors Affecting Corn Basis Relationships." Southern Journal of Agricultural Economics, 23:1(1991):147-153.

Tilley, D.S. and S.K. Campbell. "Performance of the Weekly Gulf-Kansas City Hard-Red Winter Wheat Basis." American Journal of Agricultural Economics, 70:4(1988):929-935 
United States Department of Agriculture, Agricultural Marketing Service. Grain Transportation Report. December 27, 2012. Web: http//dx.doi.org/10.9752/TS056.12-27-2012

Whitacre, R., \& Spaulding, A. (2007, July/August). Grain marketing tools: A survey of illinois grain elevators. Paper presented at American Agricultural Economics Association meeting.

Working, H. (1949). The theory of price of storage. The American Economics Review, 39(6)

Yu, Tun-Hsiang. "Essays on the Upper Mississippi River and Illinois Waterway and U.S. Grain Market." (2005). EconLit with Full Text Web. 10 Nov. 2012. 
APPENDIX

EFFECTS OF RIVER STAGES AND BARGE RATES

ON ILLINOIS CORN AND SOYBEAN BASIS

\section{River Stage: Corn Basis Graphs}
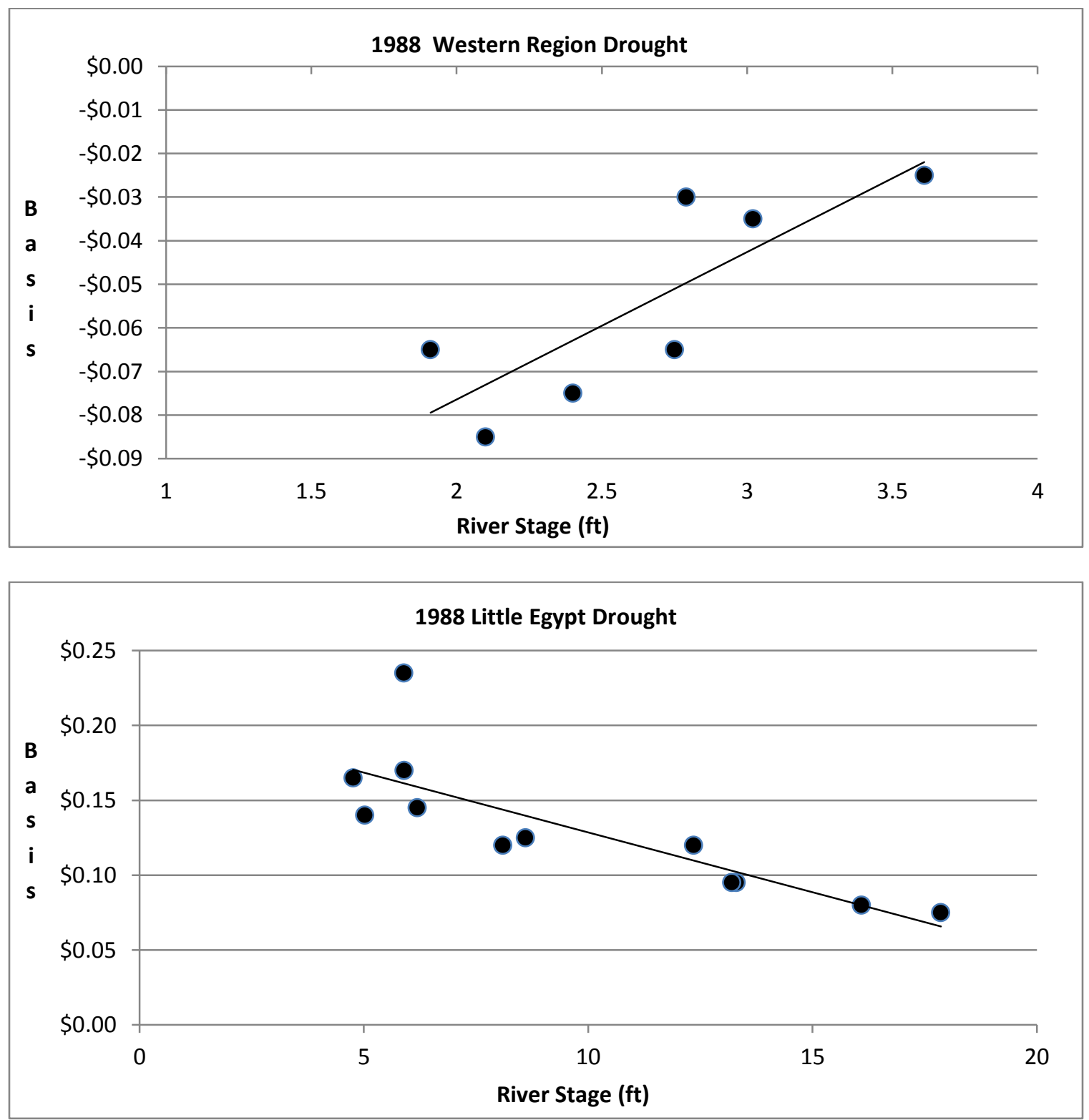

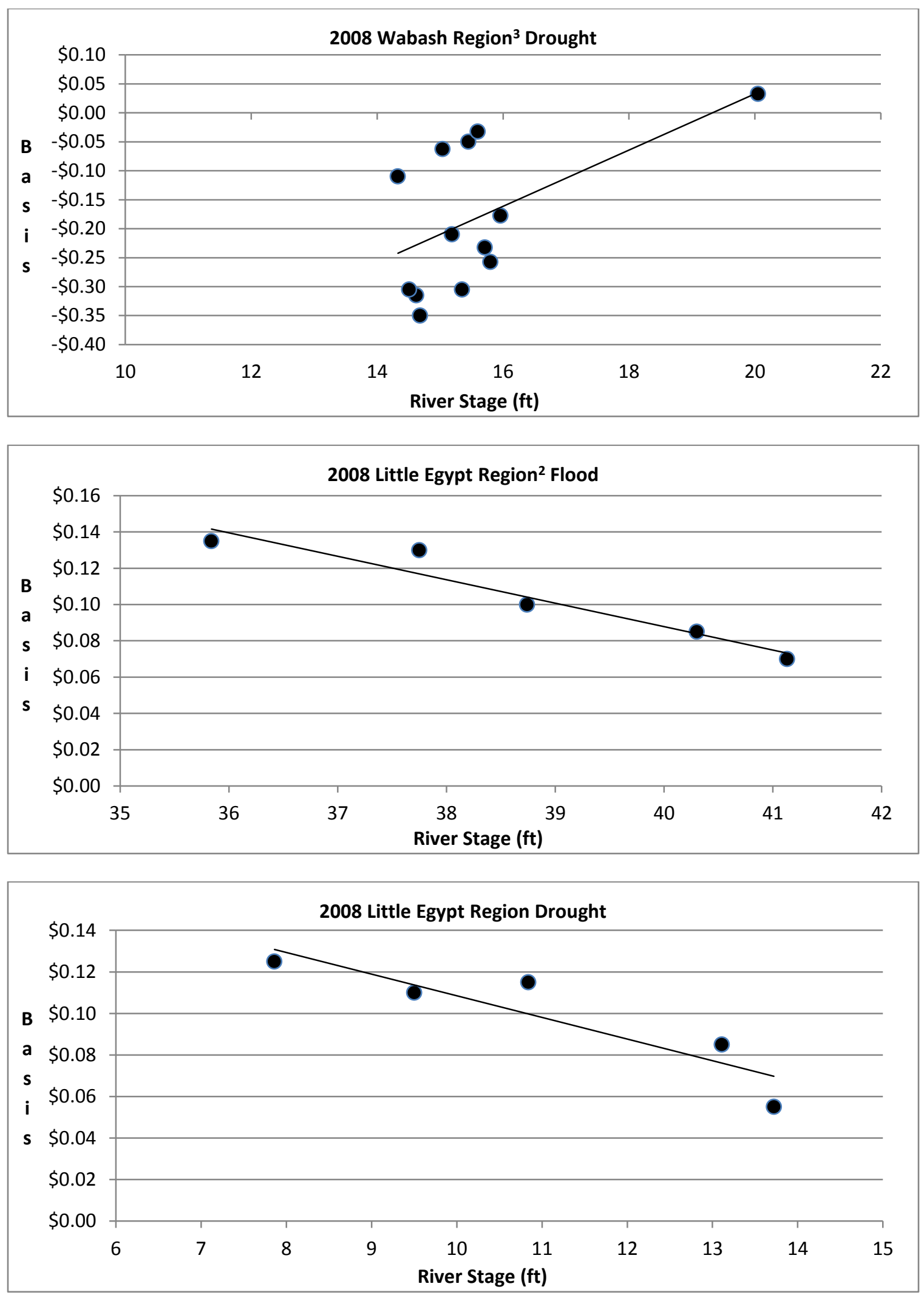

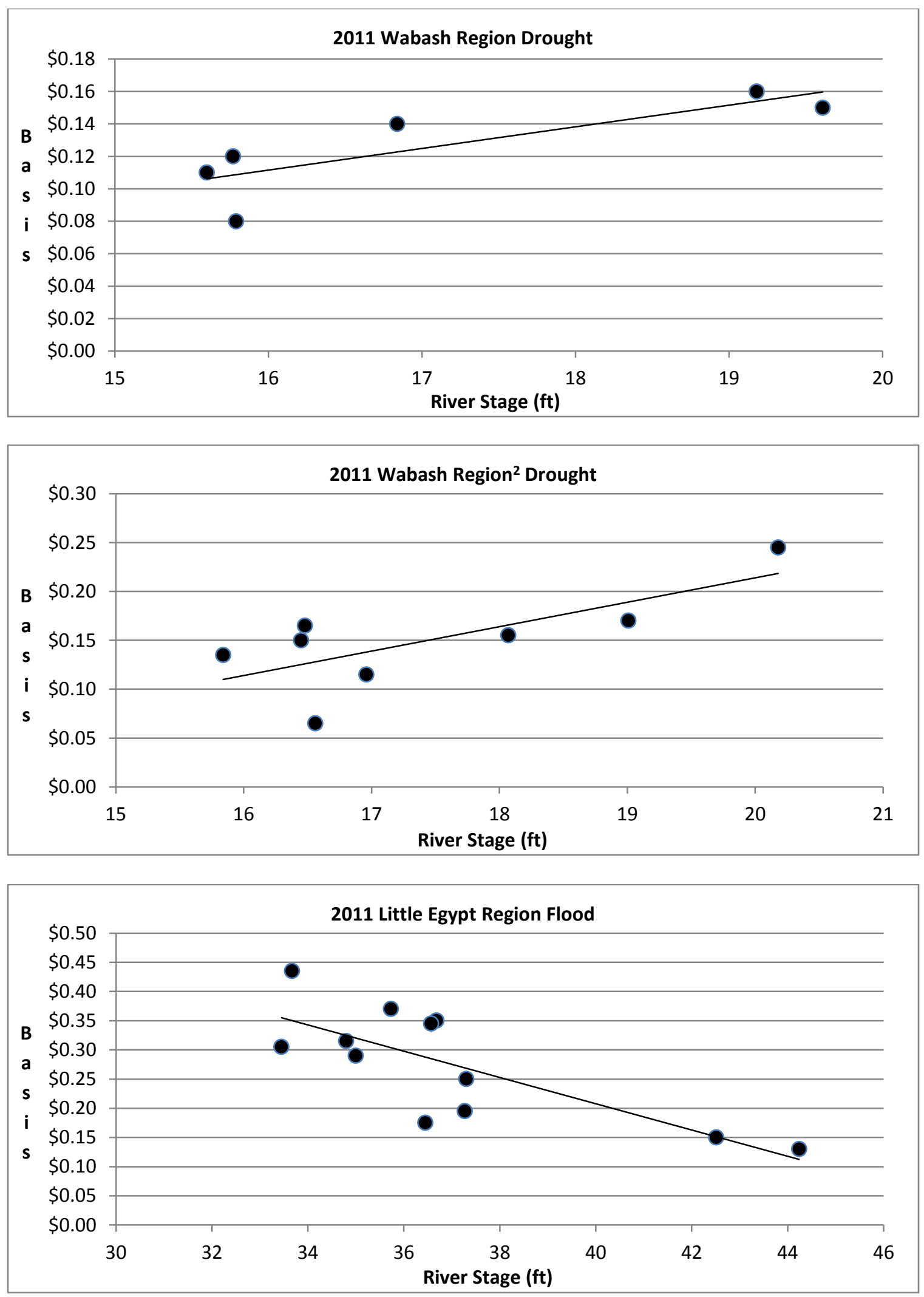

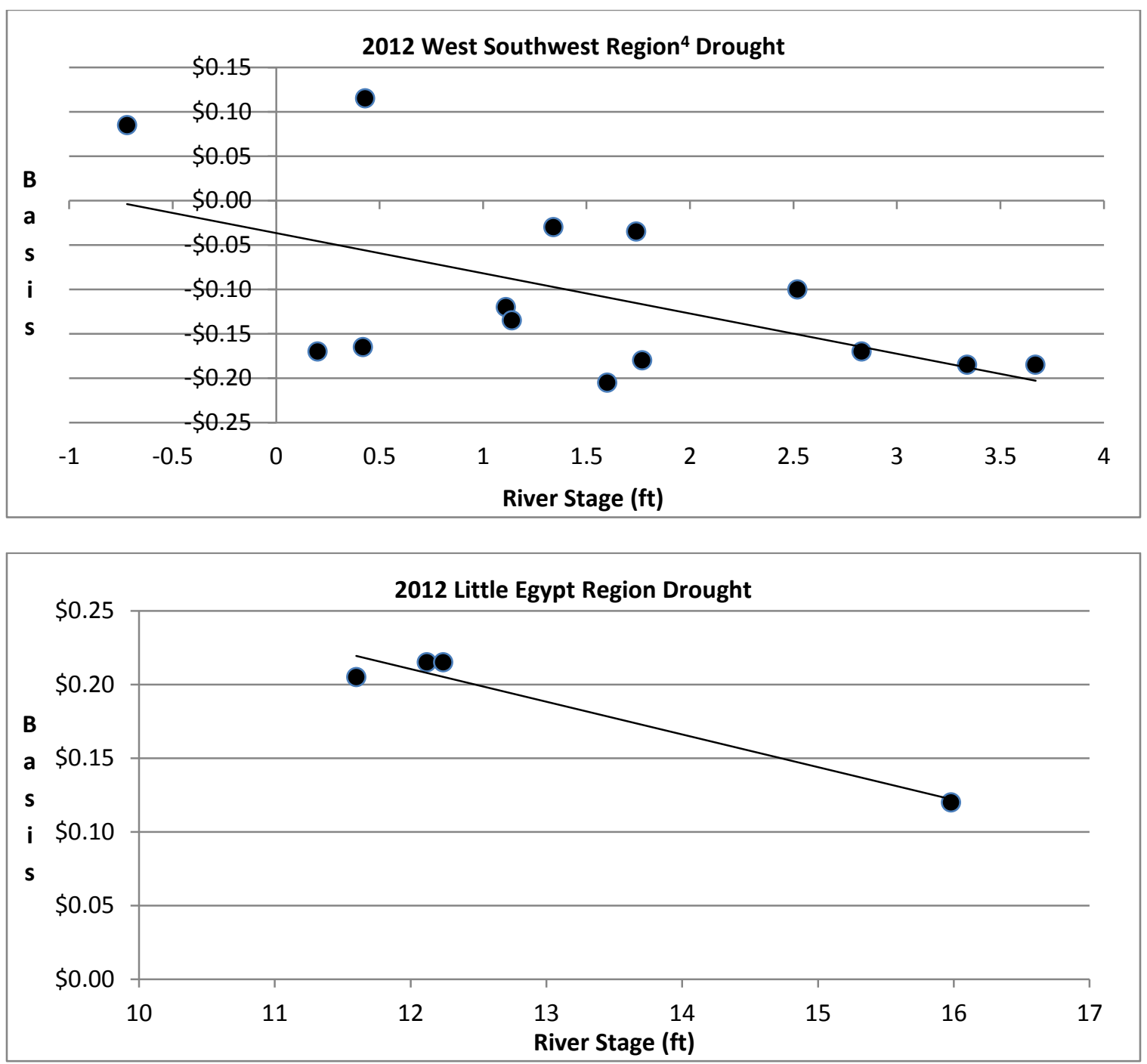

River Stage: Soybean Basis Graphs

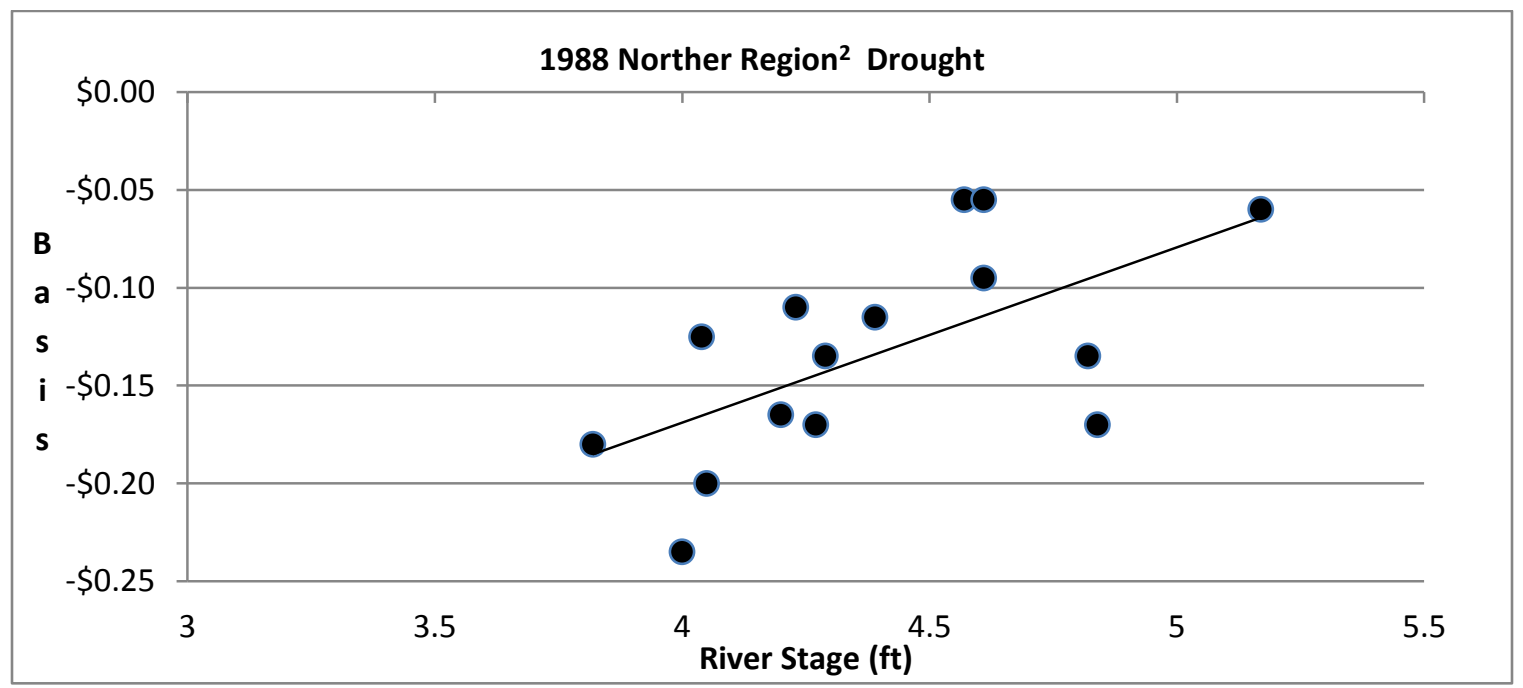



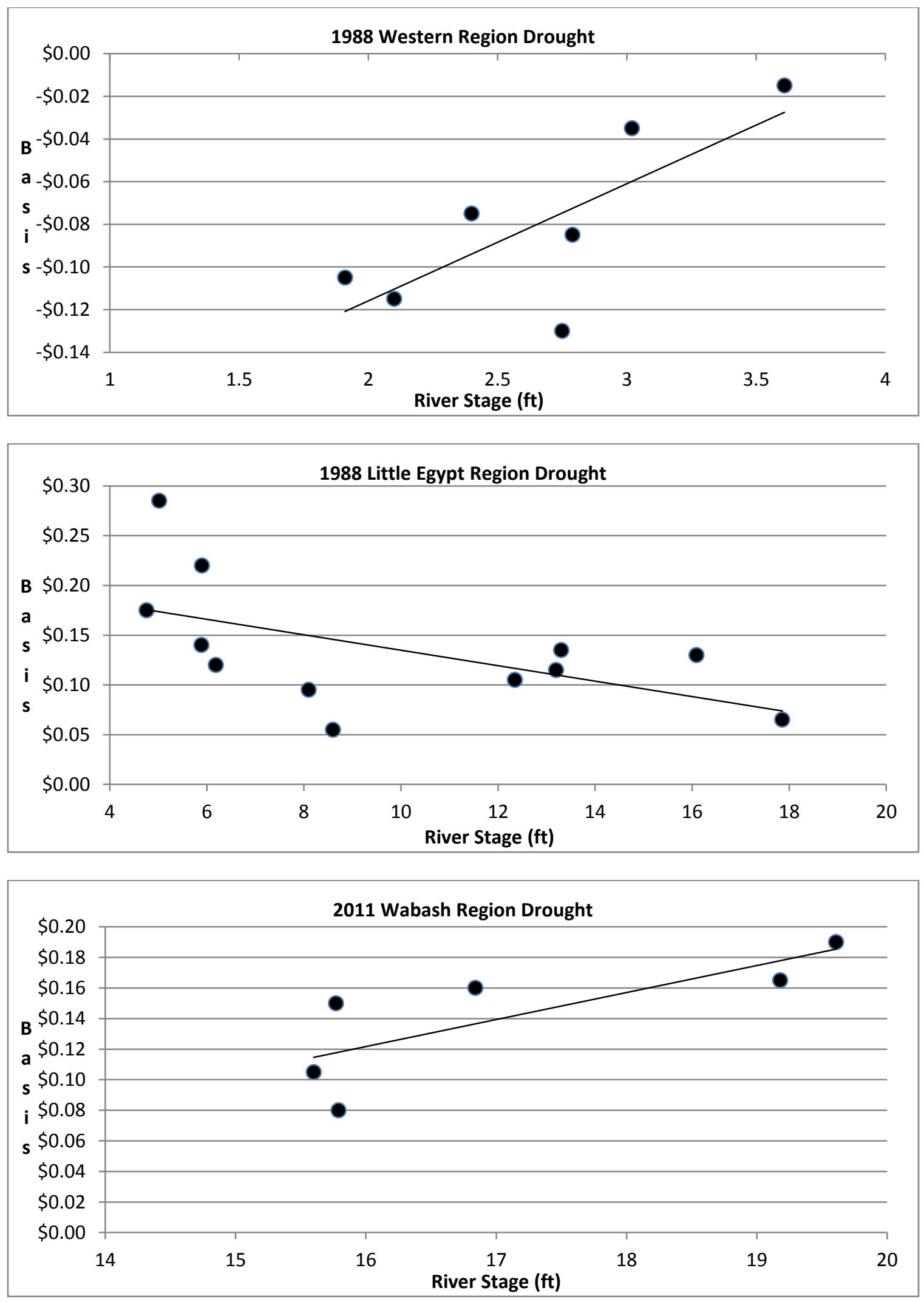

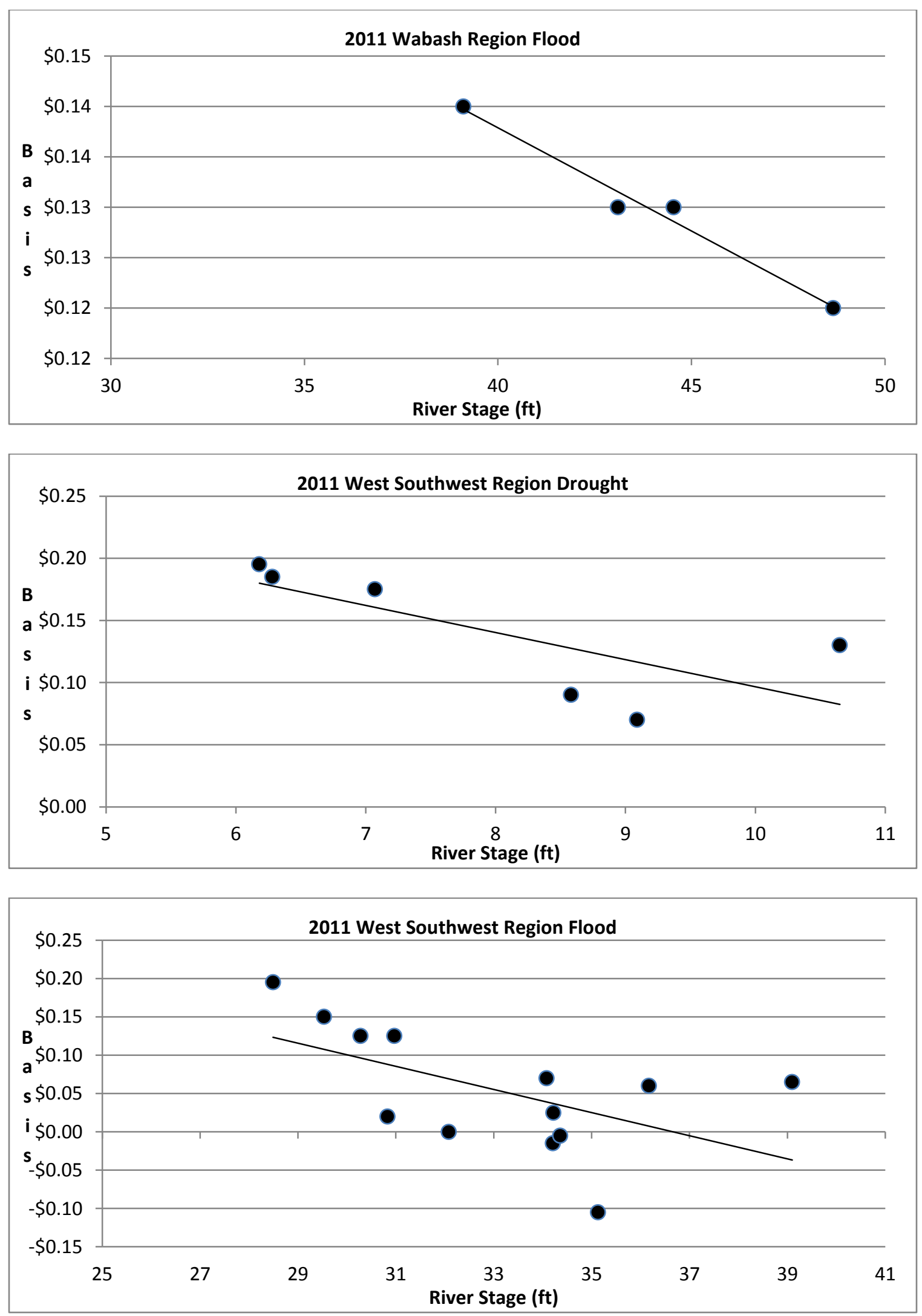


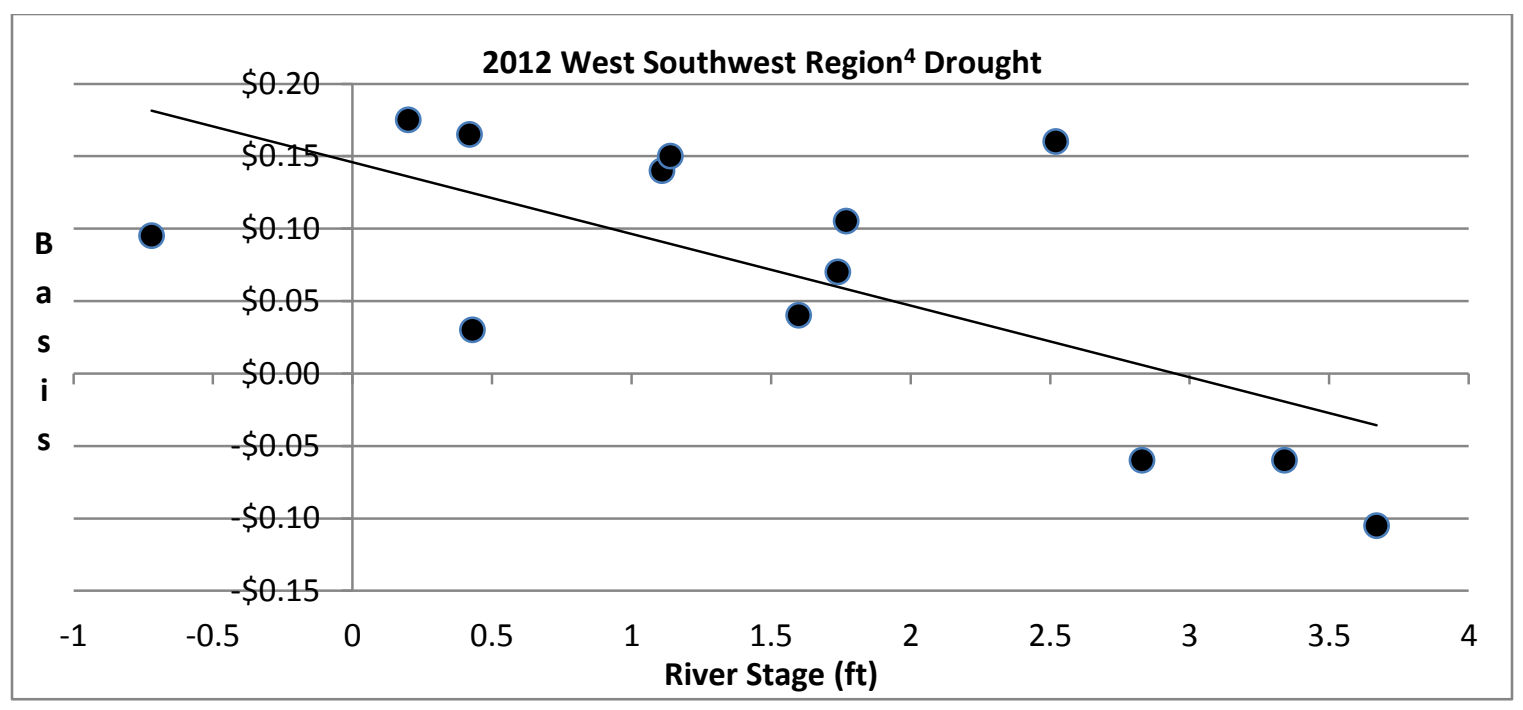

Barge Rate: Corn Basis Graphs
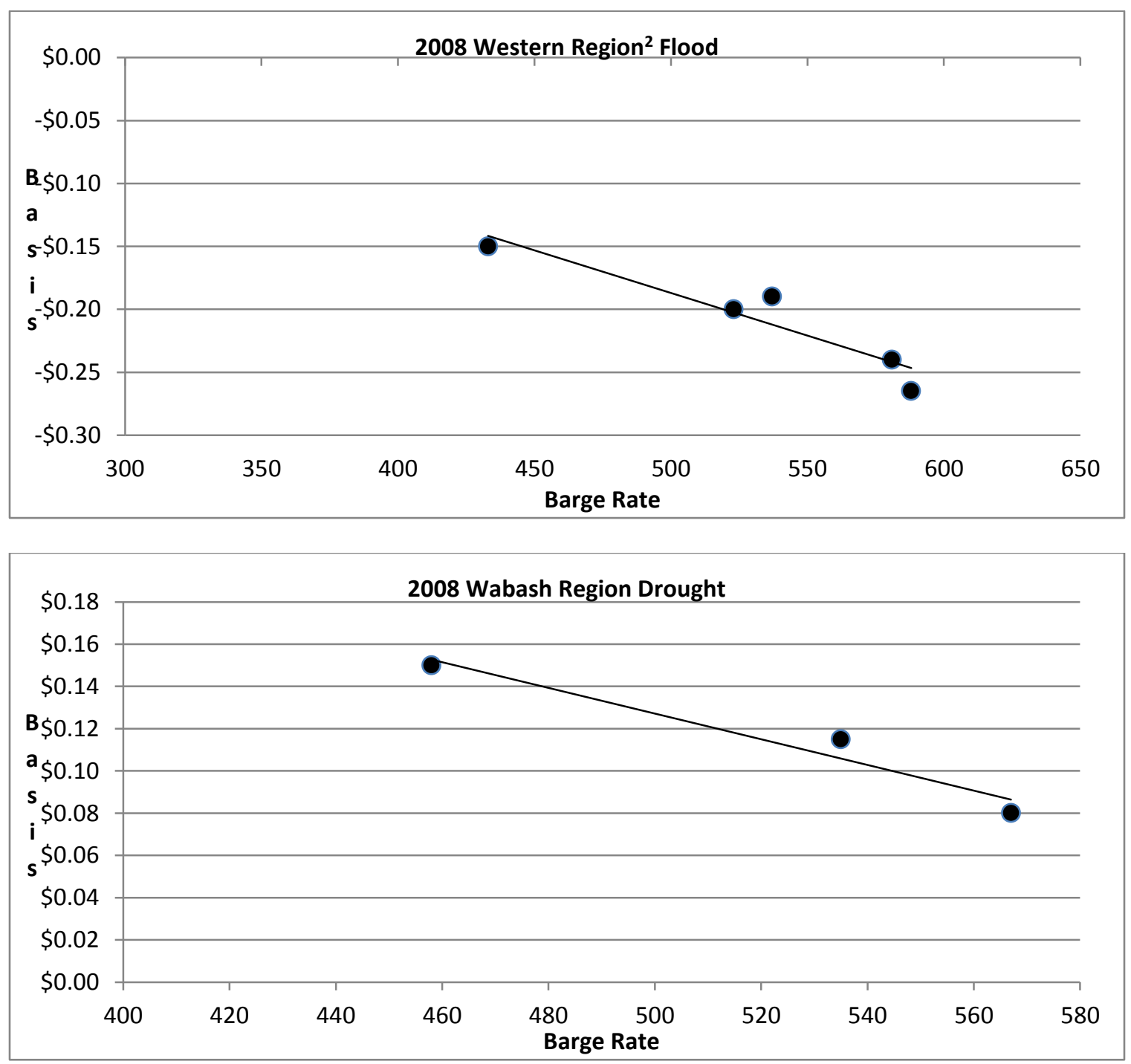

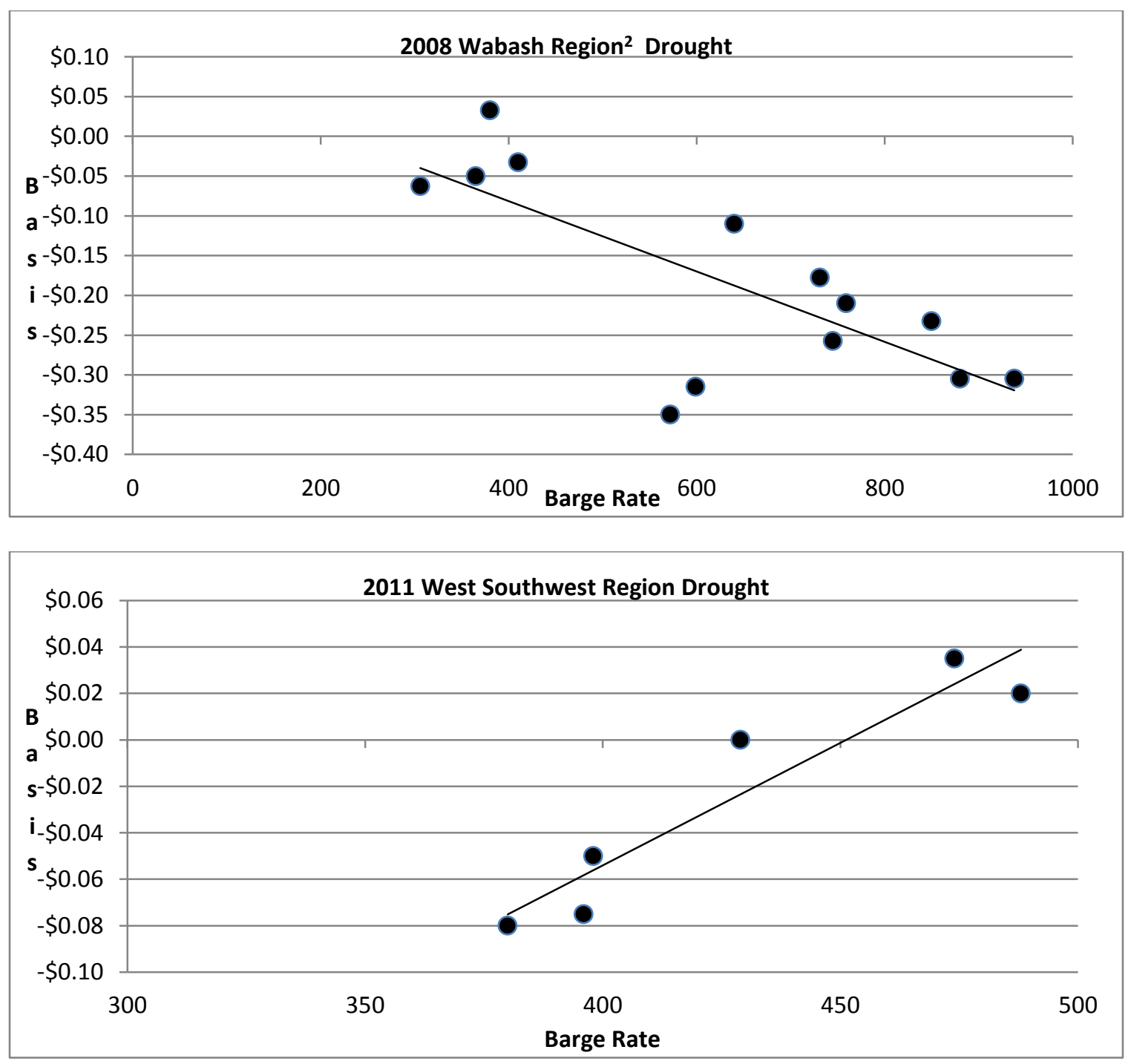

Barge Rate: Soybean Basis Graphs

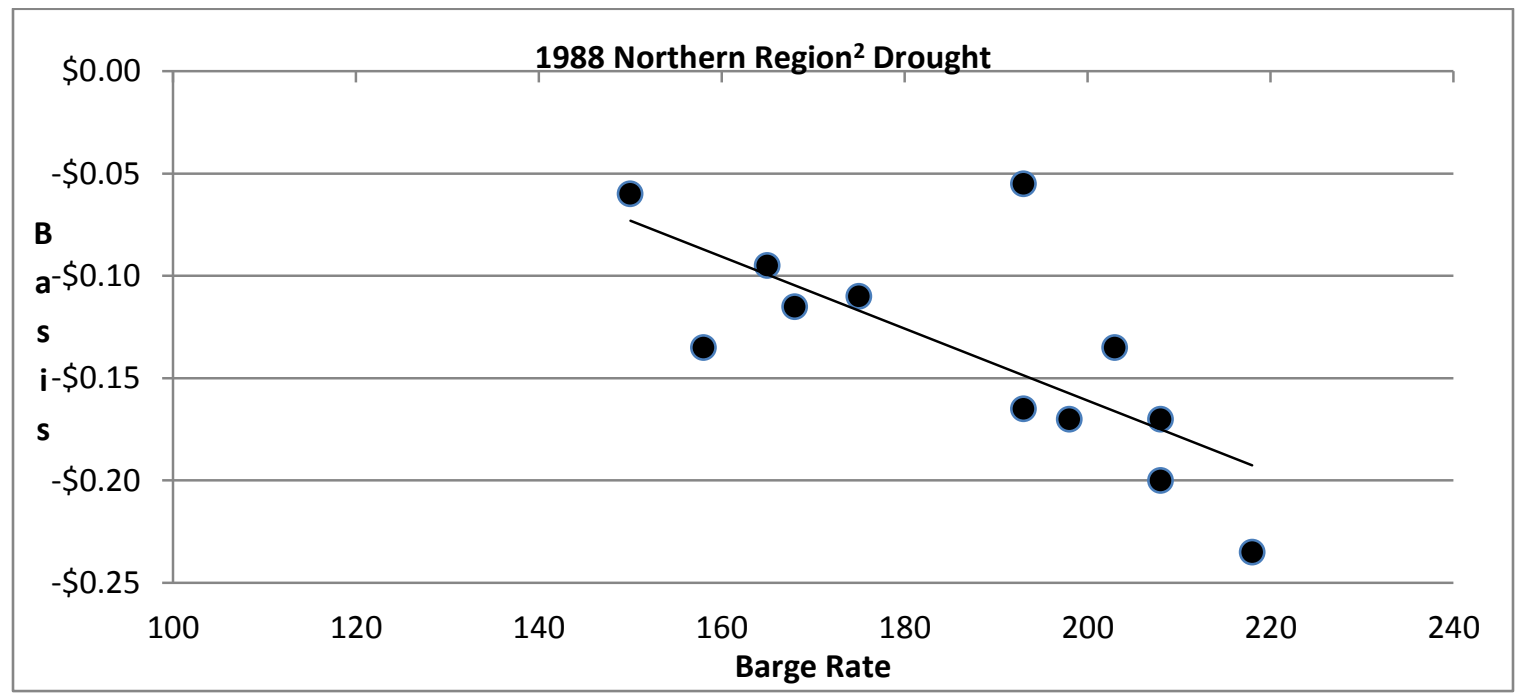



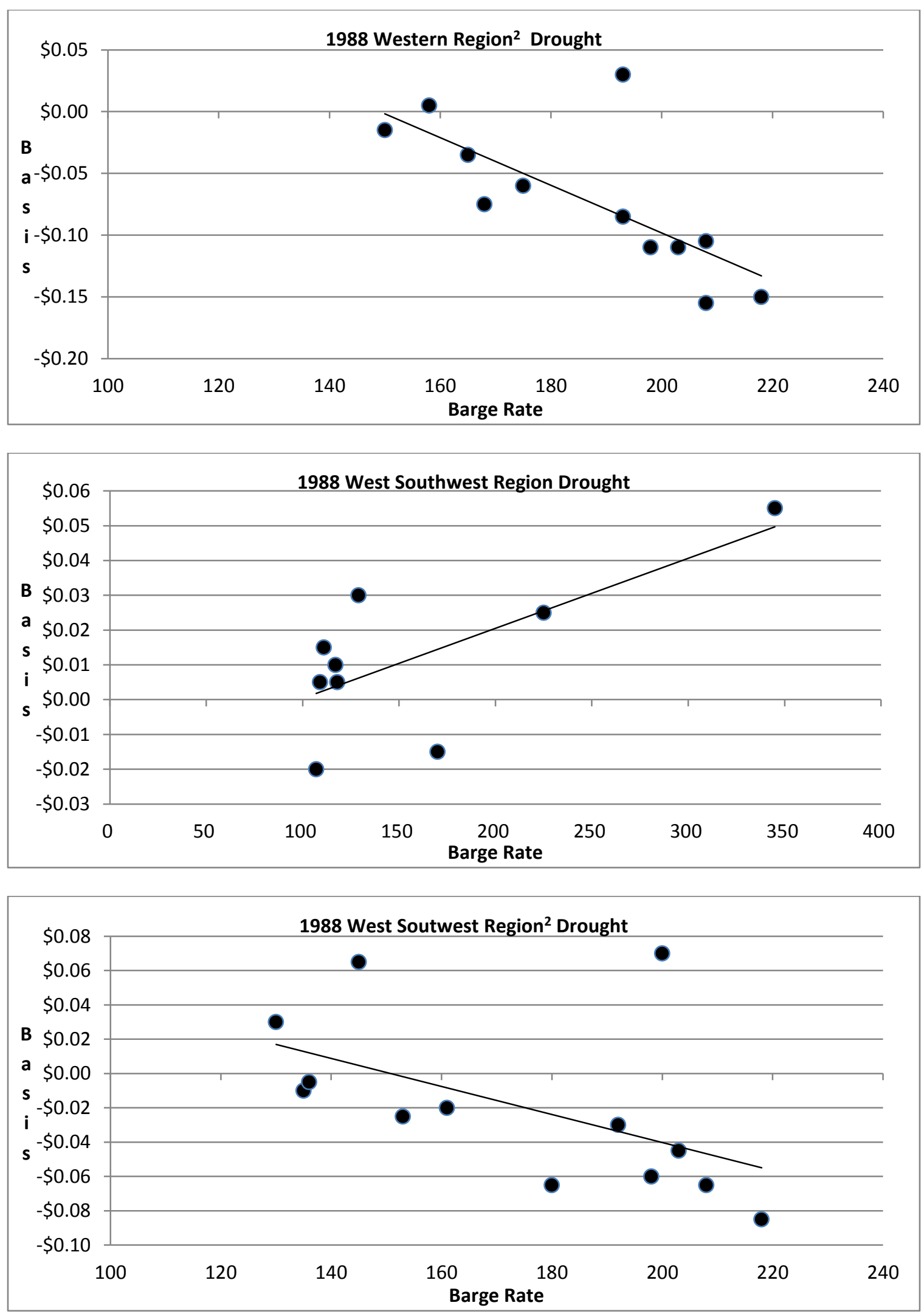

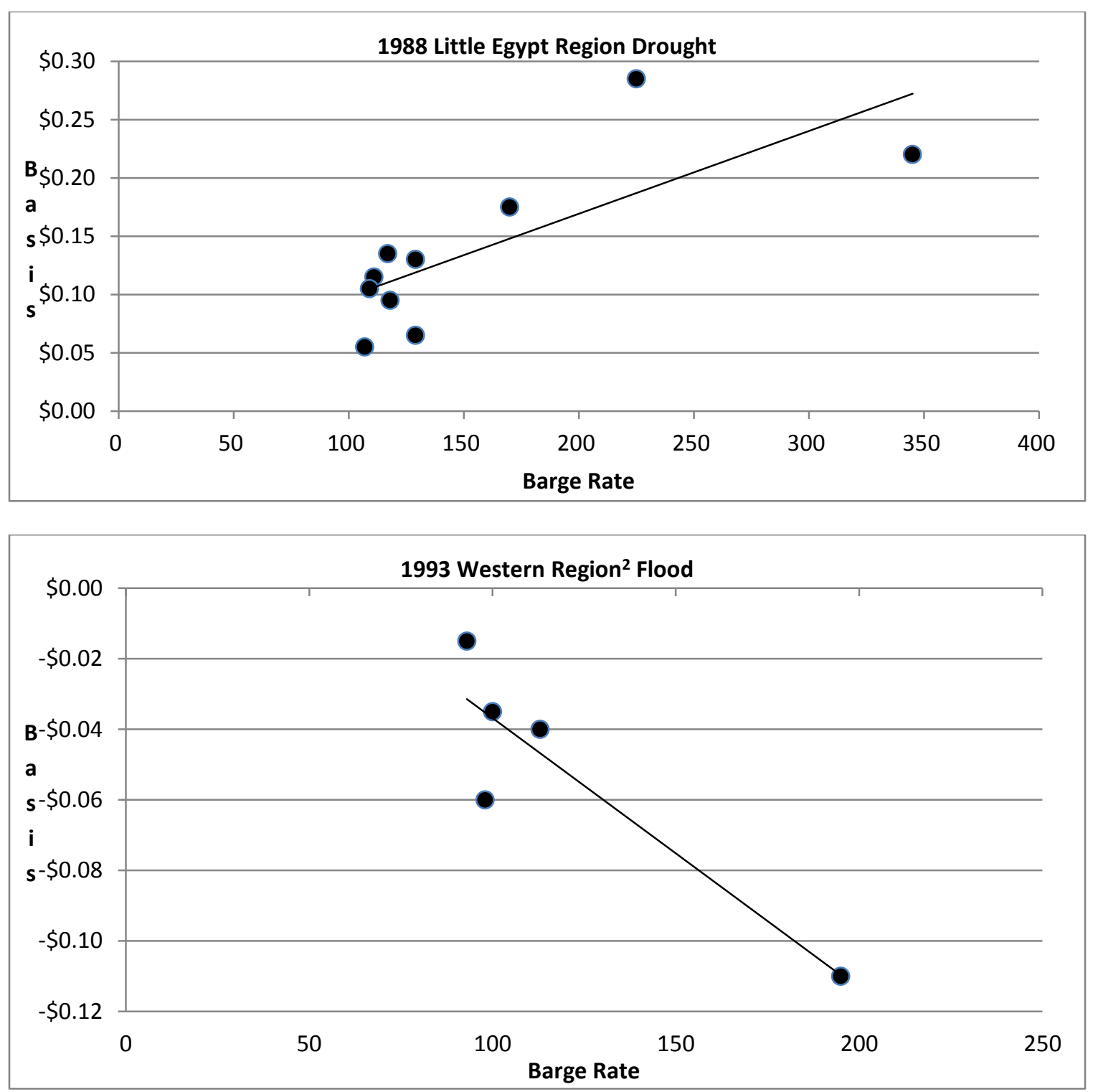

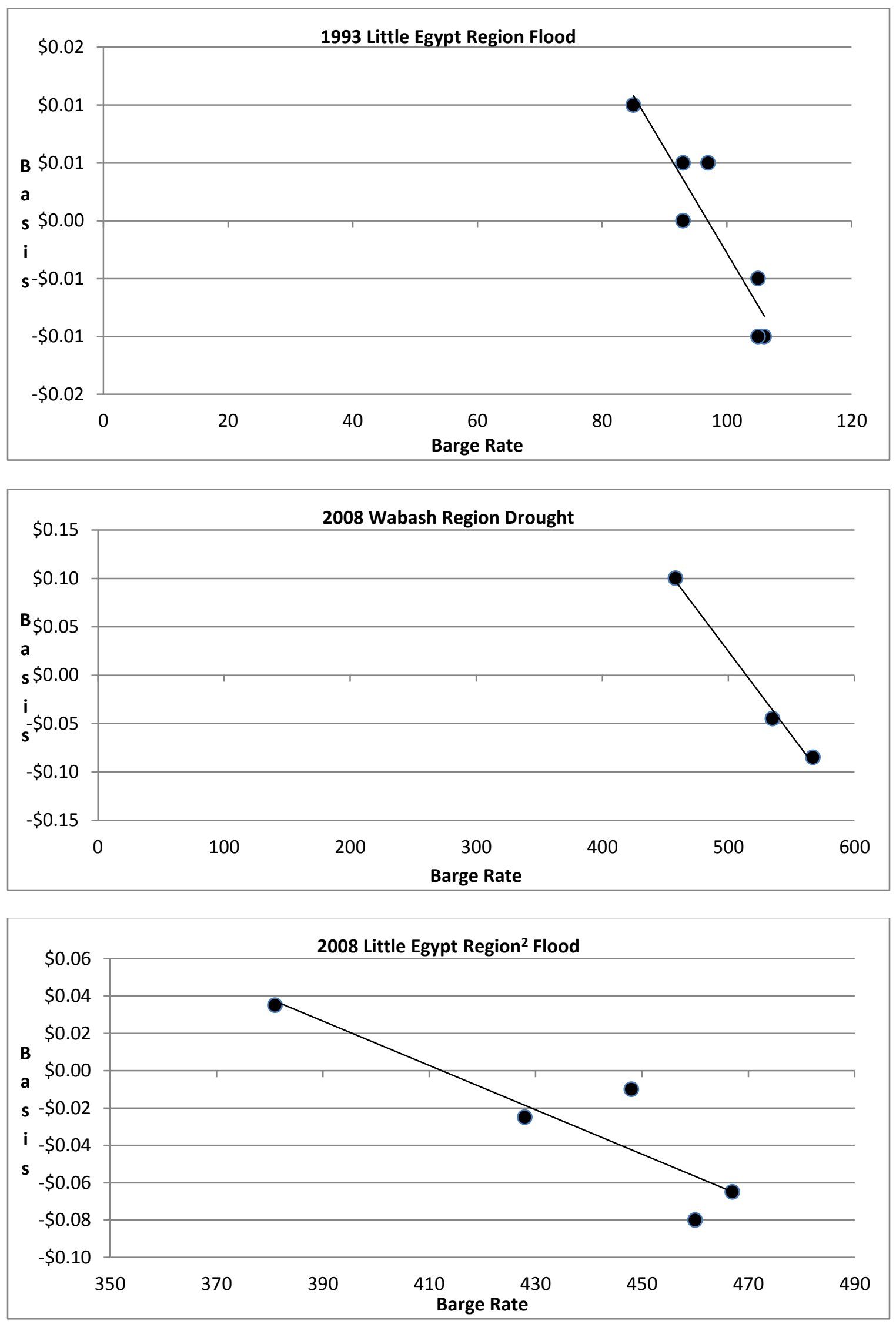

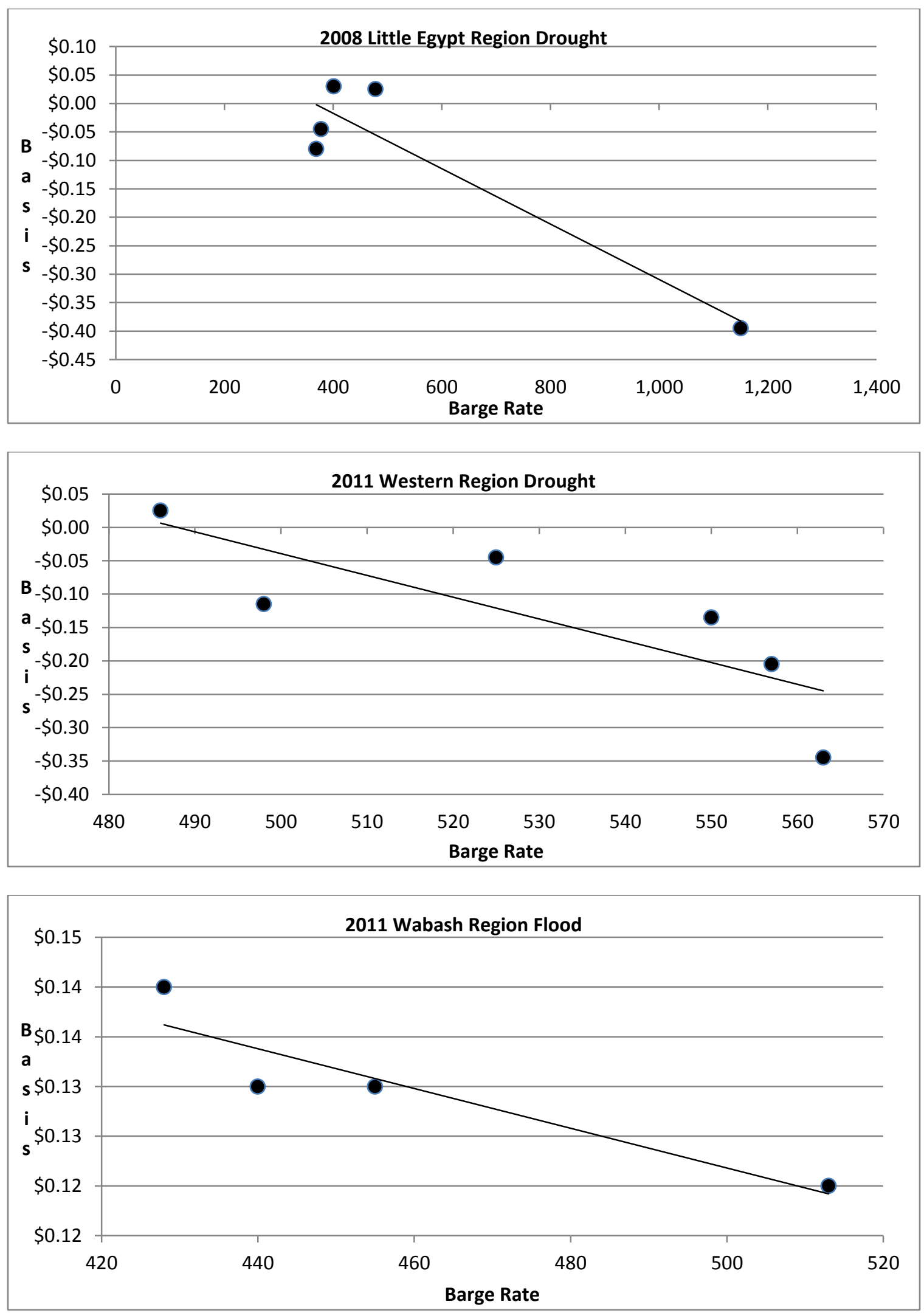

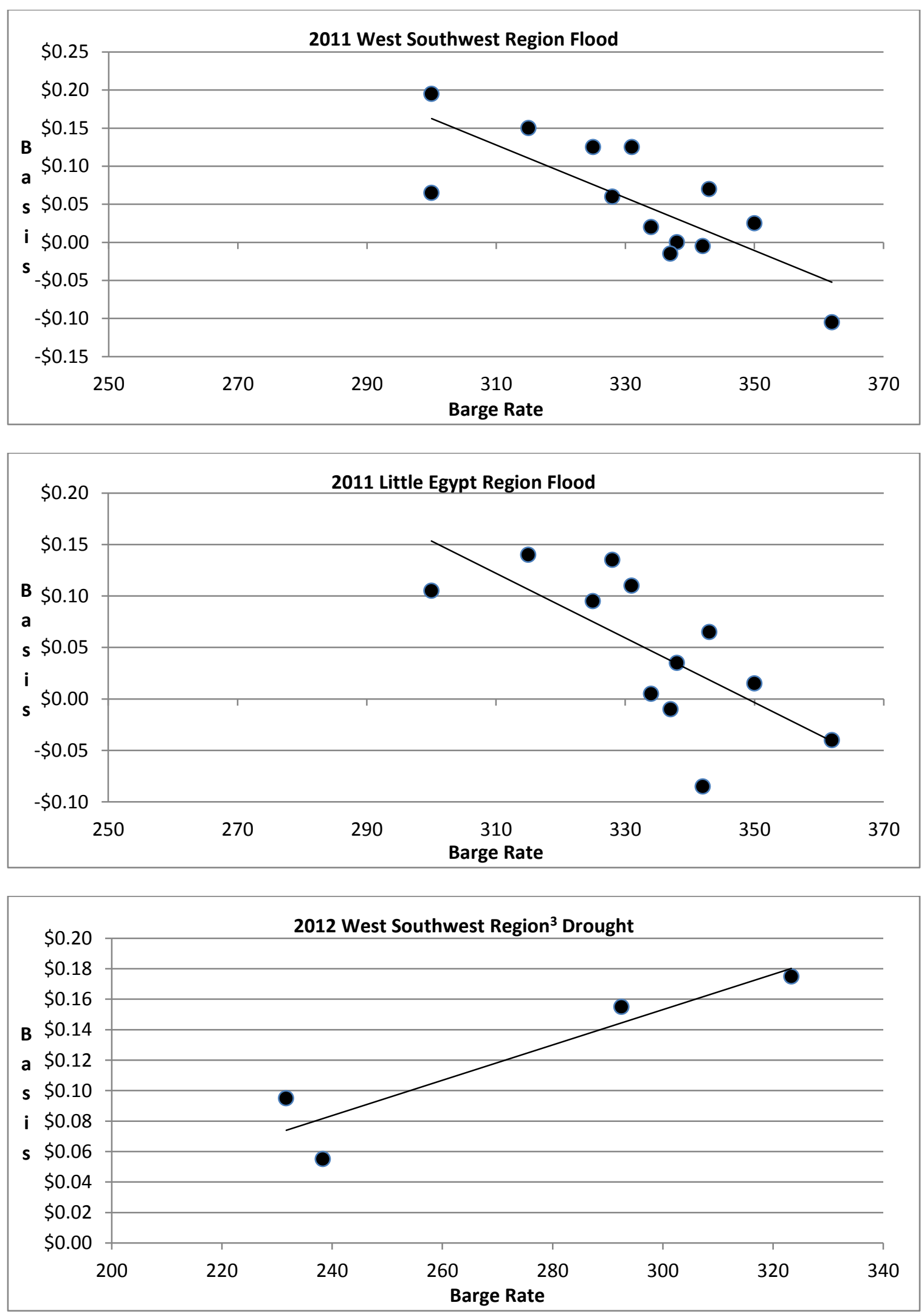
